\title{
AN OVERVIEW OF MIGUÉIS' PROSE FICTION, 1923-1968: QUESTIONS OF TIME, PLACE, SELECTED THEMATIC CONTENT AND THE AUTHOR'S VIEW OF THE WORLD ${ }^{1}$
}

John Austhi Kerr, Jr.

Even though it is generally quite laudatory, the great msss of critical opinion that exists on the writings of José Rodrigues Miguéis - particularly with regard to his prose fiction - tends to suffer from enormous variations in judgement as to the fundamental qualities of this author's works and his view of the world. To put it mildly, the reader is often left in a quandary about these matters. Furthermore, oven when one allows for their defects of fact or interpretation, with certain notable exceptions, the reviews and criticism tend to illustrate particular aspects of individual works and not their more general differences and correlations. Therefore, it is proposed that a review be made of the texts of Migutis' works of prose fiction during more than forty years of the suthor's career with regard to their settings in time and place, as well as their thematic content in therms of observable social, psychological and allied problems so that, after approptiate summarizing and correlation with the author's corpus of non-fiction, one may draw one's own conclusions as to the author's works and his cosmovisto. ${ }^{2}$ In turn, it is hoped that this will allow one to better understand Miguéis' production, both literary and extraliterary. First, the matter of the locational referents in Miguéls' works of prose fiction which were published in their entirety between 1923 and mid-1968.

If, for the moment, one considers the author's fictional works only in terms of chronological or calendar time and arranges them in sequence by earliest date, an interesting fact becomes immediately apparent: of them all, only "O Morgado de Pedra-Má"3 depicts an era which falls incontestably and entirely outside of Miguéis' own life. In this ease, the total time-span of the story covers the fifty years between 1820 and 1870. However, even this departure from the general trend of the author's writings is not a radical one, for the time-span of "O Morgado de Pedra-Má" overlaps the author's mother's girlhood. Thus, it is entirely possible that real events similar to the ones deseribed in this work were recounted to Miguéis by his mother at an early age, consequently becoming a part of his own cosmevisio, at least in terms of his understanding of Portuguese rural society of the mid-1880's.

It is possible, of course, that "Morte de Homem," "Milagre de Joane," "A Sombra," "Sob a Chuva Purificadora" and "tite, Missa Est'"4 also depict events considered by the author as having taken place prior to his own Hfetime, but in all five cases there is no clear evidence to support that assumption. For this reason, they will be considered in the same light as the overwhelming majority of his works of fiction: that they reflect social and other conditions existing during Miguéis' lifetime, whether or not they may have existed before, as many of them obviously have. The important point, in 
short, is that Migucis has taken note of these problems and called attention to their contemporaneous existence, while at the same time not limiting them strictly to the present,

It is curious to note that the next six works in order of earliest possible occurrence of their main action, that is to say, Piscoa Feliz, A Escola do Panziso, "Potica Sorte com Barbeiros," "O Cosme de Riba-Douro," "Saudades para a Dona Genciana" and "Com Eles se Amavam! ${ }^{\text {ts }}$ all contain time-cues which are relatively precise. Furthermore, these works are all concerned with Pórtugal to a great extent, although the scenes does shift to the United States in the cases of "Pouca Sorte com Barbeiros" and "O Cosme de Riba-Douro," Taken as a group, these works have to do with events occurring between 1396 or thereabouts and 1955 , with all but the smallest fraction of their main action taking place during Miguéis' lifetime.

These six works, however, are followed by four which are imprecisely set in the first few years after World War I, to wit "Uma Carreira Cortada," or in the first half of the decade of the 1920 s, that is, "Porque te Calas, Amandio?," "Os Desentendidos" and "Noite de Festa." "Entremez Um," on the other hand, appears to deal with events occurring shortly before the revolution of May 1926, while "A Linha Invisival" takes place during the abortive revolution of February 3, 1927. ${ }^{8}$ The principal difference between these two groups consists of whether or not Migueis has tied the main action of the various stories to recognizable political events; for this group also deals with Portugal, with one minor exception: "Os Desentendidos," which is set in Galicia.

As might be expected from the author's own experiences, Miguéis" "Belgeian" and "German" stories tend to form a solid block in terms of their setting in terms of time. While "O Chapelinho Amarelo"s may represent events occurring as early as 1917, the likelihood is that the year involved is much later than that. Similarly, although the last scene in "Perdão, Frau Schwarz!"10 takes place in 1946, the main action of that short story is indisputably set in 1931. However, barring these exceptions and bearing in mind that temporal references in the former work are very imprecise, "A Importảncia da Risca do Cabelo," "Cinzas de Incèndio," "Léah," "Mucha Platal", "A Dusseldorf, num Pulo," "Perdāo, Frau Schwarzl," Uma Aventura Inquietante and "Dezasseis Horas em Missțo Secreta"I I all seem to focus on the late 1920's or early 1930 's - years in which the author resided in Belgium and visited Germany.

That is not to say, however, that there are not other works of Migueis' which are set, even if imprecisely, at approximately the same time, For example, it can be deduced that "A Mancha nato se Apaga"12 is set in the decade lying between 1922 and 1932. which also corresponds roughly with one's conctusions as to "O Acidente" 3 in this regard. Additionally, while their respective temporal indications are extremely vague, both "O Primeiro Encontro com o Transcendente" and "Silvestre, os Seus Amores"14 are also set in this general period of time.

Turnitg to those stories st in the span of years ranging from the middle 1930 's to the autbreak of World War II, we find that they continue the parallelism between Migueis' life and his works, in the sense that "Uma Viagem na Nossa Terra"ts depicts the Portugal of the mid.1930's, while "Enigma! ${ }^{416}$ is set in the England of the same period, which the author visited in 1935 after a trip following the same route as that described in 
"Gente da Terceira Classe." 17 Once in the pre-war United States, Miguéis observed contitions which he recorded, then or many years later, in "O Viajante Clandestinor" "O Natal do Dr. Crosby," "Beleza Orgullhosa," "A Esquina-do-Vento," "Natal Branco" and possibly also in "Arroz do Céu, ${ }^{" 18}$ although the main action of this last story may have been conceived as occurring as late as 1947.

The war years of 1939-1945 have also found their way into several of the works already mentioned, such as "Perdso, Frau Schwarzl" and "O Cosme de Riba-Douro" 10 as a result of the total time-span these stories cover but, when we continue our listing by the earliest possible time-setting, we find that the remaining works all have the years following World War II as their primary focus. Sadly, even this hiatus in the temporal aspect of Miguéis' works of fiction had its parallel in his life, for during 1944 the author published very little, while during 1945 he did not publish at all. The reason for this eventually became clear, however, for as Migueis explained a number of years later in the autobiographical narrative, Um Homem Sorri à Morte - Com Medz Cans, ${ }^{20}$ he was gravely il at the time.

In any event, "Regresso a Cúpala da Pena" pictures the reintegration of its protagonist with Portuguese life during the months between November of 1945 and December of $1947,{ }^{21}$ while "O Anel de Contrabando" and "O "Crime Perfeito" set rather imprecisely in the 1950 's. Last of all in the works under consideration here, there is the question of "Lodo," in which temporal references are nonexistent. ${ }^{23}$ However, the very lack of time-references in that work obliges us to consider that it, too, may reflect a period of time falling between December 9, 1901 (Miguéis' date of birth) and the present: in other words, it is impossible to state the converse of the proposition and aver that "Lodo" is not set during the author's lifetime.

It is clear, therefore, that the vast majority of the author's works of prose fiction published between 1923 and mid-1968 are related to a particular segment of historical time: his own lifetime. Equally clear, however, is that Miguéis has controlled the ternporal variables to his artistic benefit, now setting a work in a precisely-defined period of time, such as in the case with Uma Aventura Inquietante, now going to the opposite extreme, as with the intemporal "Lodo," Nor are his works' temporal settings limited to these extremes, by any means. Indeed, most of them lie in a broad middle range of only relative precision in this respect, with the aspect of time being linked to the work's main action through subtle hints scattered unobtrusively here and there by means of an "infiltration" technique: a sign of a modern novelist, as Mendilow points out. ${ }^{24}$

A consideration of the aspect of geographical place also reveals striking correlations between Miguéis' life and the settings of his works of fiction. The son of a Galician-born father and a Beiran mother, the author was born in Lisbon and first visited Spain, the non-Iberian Continent, England, the United States and Brazil in that order. Thus, when one observes where the main action of each of his fictional works takes place, it is important to note that no less than twenty-four of them are set in Portugal. Of these, the Portuguese capital and its environs serves as the principal setting for fourteen works: Piscoa Feliz, A Escola do Paraiso, "A Linha Invisivel," "O Acidente," "Uma Carreira Cortada," "Saudades para a Dona Genciana," "Primeiro Encontro com o Transcendente," "Silvestre, os Seus Amores," "Noite de Festa," "Sob a Chuva Purificadora," "Porque te 
Całas, Amándio? ;" "Entremez Um," "Regresso à Cúpula da Pena" and, probably, "Lodo."25 A mixture of Portuguese rural and urban settings appears in three stories, "A Mancha năo se Apaga," "Uma Viagem a Nossa Terra" and "Como Êles se Amanaml"26 while five are set in rural Portugal: "Milagre de Joane," "A Sombra," " Tte, Missa Est", "Morte de Homem" and "O Morgado de Pedra-Má."2 9

Tuming to those works whose action takes place outside of Portugal, we find that "Os Desentendidos" ${ }^{n 28}$ is set in Galicia, while "O Chapelinho Amarelo," "Cinzas de Incêndio," "Mucha Plata!"," Uma Aventura Inçaietante, "Léah" and "A Importância da Risca do Cabelo ${ }^{429}$ depiet events in Belgium, primarily in Brussels, where Miguéis lived for three yeurs. German locales appear in three stories: "A Dusseldorf, num Pulo," "Perdaio, Frau Schwarzl" and "Dezasseis Horas em Missáo Secreta." 30 The Atlantic Ocean and the Bay of Biseay form the backdrop for "Gente ds Terceira Classe," w1 while parts of London are portrayed in "Enigmal," relatively short portions of Miguéis' life. Miguéis, however, has spent the greater portion of the last four decades in the United States. Thus, it is not surprising that by mid-1968 the United States was the setting for the second-largest body of Miguéis' works after his homeland. The stories set in the United States are nine in number; "O "Crime Perfeito'," "O Anel de Contrabando," "Arroz do Céu," "Natal Branco," "O Natal do Dr. Crosby," "Beleza Orgulhosa," "O Cosme de Riba-Douro," "A Esquina-do-Vento," and "O Viajante Clandestino," ${ }^{33}$ of these, all but the last two are set in Marnattan, and none of them strays from the Atlantic seaboard of the United States. Finally, as if to form a return link to Portugal, there is a work which is set partially in the United States and partially in Lisbon: "Pouca Sorte com Barbeiros."

The aspect of geographical place, then, which obviously consists of a limited portion of what Liddell has termed "background," 35 certainly does form a link between Miguéis' personal experience and his works of prose fietion, thus allowing us to posit further that the range of their settings about the globe in space as well as in time is an indication of the author's viewing the social, psychological and other problems appearing in these works as als which are all but universal. In addition, when one considers that the geographical locations which are merely mentioned in his works (and which do not contribute to their settings) cover most of the world, the validity of the case for this conclusion seems quite evident.

This is not the only conclusion which may be reached from an examination of the settings in which the main lines of action in the major portion of Migueis' fietion oceur, however. As noted above, all of the "American" stories mentioned are confined to the East, principally to Manhattan Island, In terms of locales, then, New York was the author's favorite city in the Americas, just as Lisbon and Brussels were the favored spots in Portugal and the rest of the Continent. Taken together, Miguéis' works of prose ficticn are markedly urban, with only one semi-rural setting in the United States - "A Esquina-do-Vento ${ }^{n 36}$ - and no rural or semt-rural settings occurring elsewhere outside of the Iberian Peninsula. Miguéis, then, is primarily an urban writer who has distinct preferences for cities in which he has lived.

As we have seen, however, he does not neglect the rural scene by any means. In addition to the one American semi-rural setting, there are three stories in which the 
jocsles shift between Lisbou and various places in the country, plus five which are set entirely in rural Portuguese areas. To these nine must be added the semi-rural locale of Migueis" one "Spanish" or "Galician" story, for a total of ten works out of forty-four exumined during the course of this study. Interestingly, of the rural or semi-nural Portuguese settings, none of them lie south of Lisbon, with the majority concentrated in the Douro River Valley or in the Beiras.

Thus, another paralellism between Miguéis' life and his works is apparent: that not only the cities which have been most favored as settings for his prose fiction but also the rural and semi-rural areas appearing most frequently in them are those with which he has had the most intimate connection over the years, either as a result of his travels or through his family. Furthermore, even though Migutis has restricted his locales in this mannes, so broad have been his travels - and consequently his cosmovisäo - that his works of fiction are truly cosmopolitan in terms of the geographical location of their settings.

\section{Social Problems}

If one analyses its thematic content, one finds that approximately $67 \%$ of Miguéis' non-fictional prose published by mid-1968 deals with a large assortment of social, psychological and certain other problems related to these two major categories. Furthetmore, of the remaining third of the author's non-fiction published during the same period, approximately two-thirds of these works dealt with literature and the arts in one way or another. The question which arises, then, is what relationships exist between these major and minor categories of non-fictional topics and the thematic content of Miguéis' prose fiction. The answer is quite revealing, for the purposes of deducing the author's view of the world, because the correlations between these broad groups are decidedly positive insofar as the primary category is concerned and almost completely negative with regard to the secondary one. To see this as clearly as possible, however, we must first consider the various topics and themes in ascending order of frequency.

In connection with the first section of the primary catezory of Migueis' writings, mamely social and socially-related problems, we find that the topic of government for the people has been treated in one article and has formed a minor theme in one novel, Uma Aventura Inquiletante. ${ }^{37}$ In contrast, while Miguéis expounded upon the general political duties of man in another article, these duties have not been an explicit theme in his fiction." Political quietismo, however, has been the main topic in one article and a relatively important theme in no less than three short stories: "Entremez Um," "Perdso, Frau Schwarzl" and "A Linha lnvisivel."39 Hypocrisy or opportunism in matters political has been castigated in one article and two short stories, ${ }^{40}$ while the poor state of public libraries in Portugal has been criticized in one article and one novel: $A$ Escola do Arraiso, in which it forms a very minor theme. ${ }^{41}$ The economic and cultural handicap of poor roads in Portugal, while forming the muen topic of yet another article, ${ }^{42}$ however, is treated so lightly in Miguéis' fiction that it can hardly be said to constitute an identifiable theme. 
Continuing on with those topics and themes which have each constituted the major focus of one of the author's non-fictional works, we find the question of national stereotypes being discussed in one article while representing a rather important theme in one short story. ${ }^{43}$. The question of guidance counselling is a bit more complicated, bowever, for even though its formal aspects are discussed in one article, ${ }^{44}$ in the author's prose fiction the subject has appeared in terms of the negative effects of a lack of formal career counselling. Therefore, these effects have been subsurned under the heading of education, along with certain other educational problems and outright deficiencies.

When we turn to the subject of unhygienic conditions, we find another example of how Miguéis has not only considered the question in a factual work, ${ }^{45}$ but also introduced it as background material in several of his works of fiction. ${ }^{46}$ Obviously, then, this social failing has been of more than passing interest to the author, as has the question of the emancipation of women, which has formed the basis of one article 7 and has appeared as a major theme in "Beleza Orgulhosa," while occurring as a minor one in Uma Aventuna Inquietante and "A Mancha nî̃o se Apaga." international problems of the United States have also merited Miguéis' attention in print, although there is again an observable difference betwoen the way he has treated of this general subject in his non-fiction and how he has dealt with it in his fictional works. Here it is not a question of exposition versus exemplification, as it was in the case of the topic of guidance counselling, but rather a difference in terms of degree and timing. Thus, Migueis has discussed in very specific terms some of the really major American domestic and intemational problems only relatively recently in his non-fiction, ${ }^{49}$ while the more minor ones, or the ones which are more universal in scope, have appeared here and there in his prose fiction over the years, more as examples of human problems which happen to be observable in the United States as well as in other countries than as peculiarly American problems. Therefore, these themes have also been included under more general headings, so as to give a fuller picture of how the author has considered the various problems involved in terms of the world as a whole.

The question of courtship and marriage, with its many problems and sccially undesirable deviations from accepted norms, is another subject which shows both correlations and differenoes between Migueist non-fletion and his fiction. As far as the American picture is conoemed, the author published one factual article ${ }^{50}$ in his homeland explaining some of the more exotic features of courtship in the United States, showing that in the main these led to the desired results even though some of American customs might appear to be rather peculiar, if not downright shocking, in Portuguese terms. American marital problems and irregularities, however, have appeared as important themes in three works of prose fiction. ${ }^{51}$ Conversely, the good side of Portuguese traditions and customs in this regard have not been dealt with as yet in Migueis' non-fictional prose - there being no need to do so - while certain deleterious aspects of courtship and marriage in Portugal and other countries have been criticized in an impressive total of fourteen works of fiction, as minor themes, as major ones, or both. ${ }^{31}$ Rather obviously, then, Miguéis considers that socially undesinable conduct with regard to the relationship between a man and a woman to be one which merits much criticism. but in terms of exemplification in fiction rather than as possibly irritating or even banal lectures on morality. Indeed, this eonclusion becomes all the more evident when we 
consider that Migucis has introduced the topic of illegitimacy as a minot theme in four works of fiction, ${ }^{53}$ while refraining from using the subject as a major topic of an article or other work of non-fiction.

The social role of freedom, on the other hand, has been treated both in Miguesis" roa-fiction and in his fiction. He wrote factual articles on freedom in terms of society at large and also with regard to an individual's need for it, if only to retreat temporarily from the demands of his socicty, ${ }^{34}$ Similarly, he treated of the questions of individual liberty versus collective responsibility, the need to escape from society in various ways and even certain instances of the repression of individual liberty in six works of prose fiction, half of which had this general subject as a major theme and half of which dealt with it as a minor one. 55 Likewise, the question of political agitation has appeared in two articles $^{56}$ and in seven works of fiction, where it is a majot theme in four. ${ }^{57}$

Superficially, at least, the problem of illness and disease is also treated in similar terms and in roughly similar proportions, since the subject appears in two non-fictional works $^{58}$ and ten works of fiction, evenly divided between major and minor themes in the various works. $\$ 9$ Here, however, there are at least two complicating factors. On the one band, the author's non-fictional discussion of this problem area forms a major, if not the major, theme in a book-lenght work: Um Homem Sorri à Morte - Com Meia Can, ${ }^{60}$ thus weighting the factual side of the author's treatment much more heavily than is apparent at first glance. On the other hand, the nature of the lliness which strikes the author in this marrative - a massive cerebral infection - introduces yet another factor into the picture: the fact that certain diseases are even now unavoidable.

Historically, of course, Man has mercly survived the inroads of disease in spite of his many attempts at tackling the problem. Only since Jenner's time has this social problem been rationalized on a large seale, with much work remaining to be done. Thus, over most of the history of mankind, the question of Ilness and diseaso has been viewed langely in terms of a social problem for which there was little or no remedy - an act of God, as it were. And it is in this manner, in fact, that the majority of the diseases are presented in Migueis: fiction, with one glaring exception: the cases of venereal disease attributed to members of the upper class in Pascor Fetiz and "Morte de Homem, ${ }^{\text {"th }}$ which can be prevented in an obvious way.

This generally unavoidable quality to the deseases which are most important in Miguéts ${ }^{3}$ works leads one to wonder whether there are unavoidable calamities of other sorts which appear in his fictional works. Interestingly enough, there are, with congenital physical deformities presented as a minor theme in one work, ${ }^{62}$ the problems of old age treated in four, ${ }^{63}$ accidents of one sort or another appearing in three, ${ }^{64}$ and natural disasters in one. ${ }^{65}$ Therefore, it scems quite evídent that Migués has not limited himself to those social problems which are inherently correctible, as a pamphleteer might, bat has chosen instead to recognize that not all human ills are capable of resolution through rationalization and good will

Curiously, the next three subjects to which Miguéis devoted two articles each, that is, certain bad effects of party politics, ${ }^{66}$ ineffectual diplomacy ${ }^{69}$ and the improvement of social relations, ${ }^{68}$ have not appeared as discrete themes in his prose fiction. In conirast, the question of technological progress and its effects, including its materialistic 
side in terms of individunls, has been treated in two articles ${ }^{69}$ and four short stories, ${ }^{30}$ while the social role of the writer is a major topic in two articles and one short story. ${ }^{11}$ Last of all in this group is the problem of poverty, which also warranted two factual articles. However, because of the complex ramifications of this subject in Miguéis ${ }^{*}$ fiction, this question will be treated later on.

Of those matters which the author considered in three articles each, we find that the problem of housing laws has found no echo in his prose fiction, ${ }^{72}$ while improper urban planning and development has formed a minor therne in two short stories. ${ }^{13}$ Deficiencies of the Press have come under fire in a major way in two fictional works, ${ }^{\text {is }}$ and have appeared as minor themes in two others. ${ }^{75}$ Criminology, which also merited three non-fictional articles 76 of the author's, appears in two works of fiction. 77 Again, however, a purcly statistical summary of Miguéis' treatment of this facet of society is misleading, for the factors which cause society to need efficient and fair criminological techniques - violence and criminality - appear as major themes in nine of Miguéis' works of prose fietion $^{78}$ and as minor ones in five others. ${ }^{79}$ In addition, Miguéis wrote three articles having to do with deficiencies in or lack of appreciation of Portugal's antional heritage: ${ }^{50}$ an area of concern which also appeared as minor themes in "Uma Viagem na Nossa Terra," "Gente da Terceim Classe" and "A Diusseldorf, num Pulo."81

Passing on to areas of greater interest to the author during the years between 1920 and mid-1968, we note that he published four articles on certain defects in organized religion $^{82}$ as well as four more articles on various problems involving socis injustice. Leaving aside this latter category of problems for the moment, since it is best treated in conjunction with Migueis' treatment of poverty and the picture he gives of the lower, middle and upper classes, one can note Migucis' exposition of various deficiencies in organized religion as a msjor theme in "Tte, Missa Est," "Como Eles se Amavam!" and "Milagre de Joane. ${ }^{83}$. The subject has represented a relatively important theme in "Arroz do CÉ," and "Dezasseis Horas em Missto Secreta," "a while appearing as a minor one in "A Importância da Risca do Cabelo," "O Morgado de Pedra.Má," Páscoa Feltz, "Gente da Terceira Classe," A Escola do Paraiso and "Entremez Um " 5 s Quite obviously, then, Migucis has broadened his criticism of this often controversial subject in his prose fiction, as opposed to his consideration of the subject in his non-fictional works,

The problem of war has long concerned the author, so it is not particularly surprising to find that his five non-fictional articles on the subject ${ }^{\text {s }}$ are counterbalanced by eight works of fiction, in three of which the subject appears as a major theme. ${ }^{87}$ Allied to this; and therefore treated slightly cut of strict numerical order, the subjects of intemational relations and general political problems have also been of great concern to Miguéis. Thus, we find eight factual articles dealing with this problem area, ${ }^{3}$ as opposed to eleven fictional works in which various aspects of this fertile ground for social problems appears, now as a major theme, ${ }^{59}$ now as a minor one, ${ }^{90}$ or both. ${ }^{91}$

Interestingly, Migucis' seven articles on various undesirable Portuguese traditions and institutions $\$ 2$ have found their thematic counterpart only in a minor way in fiction. what with the criticisms of the Spanish-style bullfights in $A$ Escole do Paraiso and the direito de pernada in "O Morgado de Pedra-Ma." ${ }^{33}$ Similarly, the area of second greatest cuncern to him in his non-fiction, that is to say various aspects of the need for Portuguese 


\section{An Oxeniew of Miguéls' Prose Fiction.}

golitical reorganization and reform, primarily during the early Republic, ${ }^{94}$ has appeared Is a theme in only four fictional works. ${ }^{35}$ In view of the fact that the major portion of Migueis. fiction appeared during the tenure of the Salazarist regime, however, this is not itprising in the slightest.

On the other hand, when one casts all political questions asjde, the subject of education is in general an unoontroversial one and one which is of fundamental importance to society - and hence to a writer who holds the problems of society as one of his major concerns. It is for this reason, perhaps, that Miguetis has examined the subject rather exhaustively in a series of fourteen non-fictional works, ${ }^{96}$ while st the same time introducing it in no less than nineteen ${ }^{27}$ of his works of fiction, in the majority of which he gives examples of how education has either miscarried or is needed for social betterment. Again, this situation is only to be expected when one considers the author's life, which has included both training for and the practice of teaching.

Besides political reorganization in Portugal and questions pertaining to the subject of education, which have represented Migueis' areas of greatest interest in his nonfictional works, there is snother social problem area which the author has examined in a great many works: the question of poverty and the consequently hard life of the lower class. Strangely, Miguéis' great interest in this aspect of society is not immediately evident from a study of his non-fictional works alone, for he devoted only two articles to the subject as such." However, when one examines Miguéis' works of fiction, one finds that the author has in reality dealt with this problem time and again. Indeed, this subject appears in the astonishing total of no less than thirty-six of his works of fiction published in complete form by mid-1968: that is to say, in all but eight of them. ${ }^{99}$

Thus, the general theme of poverty and the condition of the lower class is the most important one in the fictional works studied. Indeed, it is a major theme in seventeen of them. ${ }^{100}$ Within the subject area, it is interesting to note for purposes of arriving at an approximation of Miguéis' view of the world, that the author treats of urban poverty in twenty-four works, in which it appears as a major theme fourteen times. 101 Rural poverty is much less important, with representation in only ten of the thirty-eight stories. 102 The problem of the bad working conditions of the poor appears in six works, ${ }^{103}$ with miscellaneous related problems appearing as minor themes in three, ${ }^{104}$ In ten of these works, moreover, the lower class is represented in terms of its more admirable traits. ${ }^{\text {tos }}$ Thus, while the problem of poverty and the lower class represeats an exceedingly important theme in Miguéis' fiction, in more than twenty-seven percent of the works dealt with here and containing this problem as a theme, the lower class is presented in noble terms.

Such is not the case with Miguéis' presentation of the middle and upper classes, however. He castigates various deficiencies of the middle class, including its fear of the lower class or "rabble," in seven works of fiction ${ }^{106}$ and takes the upper class to task in line, ${ }^{107}$ primarilly in terms of its social uselessness and its rapacity. Thus, Miguéis makes definite distinctions of social utility between lower, middle and upper classes. Furthermote, he sees the matter of class structure itself as leading to various sccial injustices, which he has treated in four non-fictional works. ${ }^{10 \mathrm{~s}}$ As one might expect, he has also deait with this problem in his fiction, castigating, for example, the exploitation of others 
in eight works of greater or lesser lenght, ${ }^{169}$ In tum, people's exploitation of others has given rise to another social deficiency: the need to emigrate to escape economic and other oppression in one's homeland. This problem appears in the thematic content of no less than eigit of the forty-four fictional works discussed herein, ${ }^{110}$ with the related myth of the American "El Dorado" occuring in two. "11 Thus, the whole complex of problems arising from social class structuring and the oppression of the poor has many interesting ramifications in Miguéis' writings, with his primary emphasis oceurting in his prose fiction: that is to say, that portion of his prose in which the greatest emotional impact is likely to be generated in the reader by his exposition of these problems.

Poverty, class differences and related problems are not the only areas for which the author has shown a predilection in his prose fiction, however. In addition to those problems already discussed, there are two other groups of them which have been criticized in Miguéis" fiction rather than in his non-fictional works: one group concerning a variety of social problems affecting more than one person, and another containing a selection of similar problems affecting the individual. Among the problems occurring in the first group one finds that the theme of prostitution has appeared in nine works, ${ }^{112}$ gambling in four, ${ }^{113}$ alcoholism in four, ${ }^{114}$ hypocrisy in social situations in five, ${ }^{11}$, medical incompetence in three, ${ }^{116}$ defects in the Portuguese and Belgian judicial systerus in two, ${ }^{117}$ and a wide variety of economic difficulties in the impressive total of fifteen. ${ }^{118}$ In the second group, the problem of alienation from society which does not involve insanity occurs as a theme in five works of fiction, ${ }^{119}$ with specific contrastive instances of vagabondage ${ }^{120}$ and exile $e^{121}$ occurring in two and three fictional works, respectively. The latter type of social alienation naturally leads to the question of an emigrant's adaptation and adaptability to foreign surroundings, which the author has treated of in no fewer than eleven of his works of fiction ${ }^{122}$ and to the problems surrounding a person's reintegration with a society from which he has become alienated for one reason or another; a theme that can be noted in five fictional works of Migueis', ${ }^{123}$ And, if one but looks at the outlines of his life, it becomes apparent that problems of social alienation, adaptation to foreign environments and reintegration with his native culture have done more than metely touch on the author's life.

In sum, then, it is evident that problems attendant upon poverty and class distinctions, education, coonomic difficulties, violence and criminality, interpersonal relationships between man and woman, religion, emigration, adaptability and reintegration and tllness have been Miguéis' favored topies in his prose fiction, insofar as social problems are concemed. Although this does not exhaust the list of the social problems with which he deals by any means, it is clear that many of these problem areas have affected the author in one way or another in his personal life. Furthermore, when one compares Miguetist treatment of social problems in his non-fictional works with his treatment of them in his fictional ones, the positive correlations existing between then are striking. These correlations are not total ones, of course, thus providing us with insights into the fact that a writer's artistic production may be both more limited in soope than his factual corpus in some areas, yet go far beyond the boundaries of his non-fiction in others. 


\section{Psychological Problems}

The second major section in the primary category of topics discussed by Migueis in his non-fictional prose, namely psychological and psychologically-related problems, is also well-represented in the thematic content of his prose fiction, although not as heavily as social and socially-related problems. Indeed, psychological problems appear much more frequently in the author's fiction than in his non-fiction, even if we take into consideration the facts that he has dealt with mental retardation and other psychological aberrations in a long report ${ }^{124}$ and described and discussed both hypochondria and eertain personal psychological effects of a grave illness in the autobiographically-oriented, book-lenght narrative, Um Homem Somi d Morte - Com Mefa Cana. ${ }^{125}$

Furthermore, this group of problems shows another interesting characteristic, in that some of those we have considered to be psychological ones also border on the realm of social problems. For example, Miguéls published one article on the subject of avarice, ${ }^{126}$ while also treating of it in five fictjonal works. ${ }^{12 ?}$ In the natural course of events, the avaricious may easily prey on more gullible souls, a fact substantiated in Miguéis' fiction by his treatment of people's gullibility in "Enłgma!" and Uma Aventura Inquietante. ${ }^{128}$ Both avarice and gullibility may be considered to be prychological problems when considered in terms of two separate individuals, but when one person dupes another, the act is also of social relevance.

Similarly, the quasi-social but also psychologically-related problem of superstitious beliefs is also treated in a total of one article ${ }^{129}$ and five works of fiction, ${ }^{196}$ while the question of an apathetic of indifferent attitude towards the well-being of others another bordeline case - has been discussed in five articles ${ }^{131}$ and exemplified in four fictional works. ${ }^{132}$ Finally, the related and more extreme manifestation of this attitude - outright cruelty - has appeared as a theme in two novels ${ }^{133}$ and two short stories. ${ }^{134}$

Turning to the problems treated both in Migueis' fictional and in his non-fictional prose which are more clearly psychological in nature, it is to be noted that these rango from the very serious to the exceedingly minor. Thus, he dealt at some lenght with the subject of mental retardation and related psychological abnormalities in a report he submitted to the Junta ds Educaçato Nacional concerning his three years of study at the University of Brussels. ${ }^{195}$ These problems have also appeared as themes in "Gente da Terceira Classe," "L6ah" and "Porque te Calas, Amảndio? "136 Among the relatively more minot psychological problems, Migutis has dealt with certain effects of insecurity in one article $\mathrm{I37}^{37}$ and used this problem as a major theme in " $\mathrm{O}{ }^{+} \mathrm{Crime}$ Perfeito" is is Another article concerning deleterious effects of great success in life ${ }^{139}$ did not find its counterpart in the thematic content of Migucis' prose fiction, but a large number of other psychological problems of this nature have been registered as themes in the fictional portion of the author's body of writings. Thus, hedonism and gluttony have appeared in three fictionnl works, ${ }^{140}$ extreme passivity or the inability to act in four short stories ${ }^{141}$ and prychosomatic illnesses in two. ${ }^{142}$ The desire for revenge has appeared in three fictional works, ${ }^{143}$ while one person's desire to subjugate another of to be subjugated by another is observable as a bipartite, complementary set of themes in "O 'Crime Perfeito" and "Gente da Tetceira Classe." ${ }^{n 44}$ The problem of moral cowardice has formed a major 
theme in "A Mancha nalo se Apaga,"14* while an obsessive need for absolute liberty is an important part of the thematic content of "A Esquina-do-Vento."146 Finally, the problems of sleepwalking, sensationalism and ostentatious behavior have all appeared as minor themes in A Escola do Panaiso, Uma Avertura Inquietante and "Mucha Plata!", respectively. ${ }^{147}$

As with social problems, some of the psychological aberrations appearing in Miguéis' prose fiction also fall inte what might be termed affinity groups, One of these is made up of otherwise unrelated emotional problems of which one - the effects of humiliation - has been treated in the author's non-fiction as well as his fietion. "4. In addition, the problem of extreme grief has appeared in "Como Eles se Amavam!"14." and that of shyness in "Milagre de Joane" and "Saudades para a Dona Genciana," 50 while certain effects of timidity are observable in "Léah" and "Porque te Calas, Amän. dio? " 151 Excessive emotional repression and its all-but-homicidal repercussions have formed a major theme in "O "Crime Perfeito." 1 " Finally, various problems arising from lack of affection have been treated in "A Esquina-do-Veato," Pascod Feliz, "A Mancha näo se Apaza" and "Morte de Homem."153

A second group of interrelated themes has to do with abnormal sexual behavior of tendencies. Thus, both Mimi in "Saudades para a Dona Genciana"154 and Dalilah in $A$ Escola do Paraiso is s exhibited a tendency towards precocious sexuality which was out of the ordinary. Sexual promiscuity plays a part in "Silvestre, os Seus Amores" and "A Esquina-do-Vento,"is6 while morbid sexual curiosity appears as a theme in " $O$ 'Crime Perfeito'," "Saudades para a Dona Genciana"' and Uma Arentura Inquietante ${ }^{15}{ }^{7}$ On the hand, sexual repression and frigidity affect, respectively, Prof. Ch. Brown, Ph. D., of "Enigmal" 158 and the nameless, wanton woman of "O "Crime Perfeito'."159 This is already a fairly broad range of sexual abnormalities or abnormal tendencies, but it is still not the complete range of such problems to be found in Miguéis" works. Aside from the relatively minor instances of lechery appearing in $A$ Escola do Puraiso, ${ }^{160}$ one may observe various effects of homosexuality in "O Natal do Dr. Crosby, ${ }^{* 161}$ in which the problem constitutes a major theme, or in "Léah", 162 where it can be considered to be of only minot importance in that story's thematic content. Finally, the question of lesbjanism appears as a minor theme in "O Crime Perfeito", ${ }^{* 163}$ as part of the psychological configuration of the work's main feminine character.

Allied to this general area of concern is the problem of jealousy, In "Beleza Orgulhosa" and "Silvestre, os Seus Amores," one finds an exceedingly jealous husband and lover, respectively. 164 In "O Acidente," 1s' the night watchman's female companion is also extremely jealous, thus exemplifying the problem from the point of view of a woman. On the other hand, not all types of jealousy arise from questions of mature sexuality, and 50 the suthor rounds out the picture in A Escola do Paraiso with 2 description of little Àgueda's jealousy towards her new-born brother, Gabriel, who his naturally come to monopolize much of their mother's atteation. ${ }^{\text {is }}$

Turning to other psychological problems of various sorts which appear as themes in Miguéis' writings, one finds that excessive authoritarianism in parents or parental substitutes has been criticized in eight of Miguéis" fictional works. ${ }^{167}$ Various aspects of frustration and disillusionment with life have been treated in three short stories, ${ }^{168}$ while 
various forms of fear have appeared in no fewer than seven nowels and short storios. 169 of these, particular note should be taken of the author's treatment of hypochondria in Uim Aventuna Inquiletante and A Escola do Paratso - a subject of considerable inportance in the thematic content of the semi-autobiographical work, Um Komem Sorri a Morte - Com Meir Cane 170

In addition, it is of especial interest to note that one result of fear-prejudice towards others - is the most common of all the psychologieal problems in Miguéis' works, appearing in no less than fifteen fictional works. Of these, xcnophobia is treated in five works, ${ }^{171}$ anti-semitism in seven, ${ }^{172}$ other sorts of racial prejudice in four ${ }^{13}$ and particular national prejudices in six. ${ }^{174}$ Unfortunately for the "melting-pot" theory so often mentioned in connection with tho United States, in four of the last six works there are refloctions of American prejudice towards particular sthric groups and recent immigrants. ${ }^{175}$

Such attitudes, of course, can lead to a certain loneliness in a sensitive person's existence, although many other factors can also cause such a state of mind. Nevertheless, the fact remain that loneliness is another important theme in Miguéis" fictional works, occurring in a total of eight of them. ${ }^{176}$ Whether he is a native or a foreigner, old or sick, a person may also suffer from insomnia - a fact registered in the thematic content of eight of the author's fictional works, ${ }^{177}$ Similarly, almost cverybody suffers at one time or another from guilt and remorse, each of which appears as a theme in three of Miguejis' short stories. ${ }^{178}$ People may worry excessively about their sanity, as the protagonists do in "O 'Crime Perfoito"," and "A Linha InvisiveL" 39 . They may actually become insane, as several characters do in six of Miguéis novels and short stories, most notably in Püscoa $\mathrm{Feliz}^{180}$ Finally, they may commit suicide, as described in six of the author's fictional works. 181

This completes our review of the main lines of Miguéis" exposition of psychological problems in his writings, both fictional and non-fictional, pablished in complete form between 1920 and mid-1968. Rather obviously, the author has been attuned to the existence of a great variety of such problems afflicting mankind. Even if one considers Only his major areas of interest in decreasing order of frequency of appearance, one finds that he has dealt with emotional problems, prejudice of various sorts, sexual ahnormalitios, authoritarianism, insanity, suicide, loneliness and insornia; stlll a wide range of subjects. Thus, even though the thematic content of Miguéis' prose fietion in terms of psychological problems is somewhat reduced in comparison to its thematic content having to do with social problems, occurring as identifable themes in only forty of the forty-four works considered here, the differences between the two thematic categories in terms of overall magnitude are relatively minor. What is important to note, bowever, is that the author, while treating of social and socially-related problems in numerous factual works as well as in all of his prose fiction, has dealt with psychological and psychologically-related problems in only a relatively few non-fictional works. To sum Up, then, Miguéis' sacial consciousness, as exhibited in his writings, is both cotaterbalanced and amplified by his concern for and treatment of human problems of a psychological nature, primarily in his prose fiction. 


\section{Other Aspects}

At first glance, jt may seem that a second major category of Migueis' non-fictional prose, i.e. that which does not have to do with social or psychological problems, has not been reflected as discemible content in his works of fietion. However, this lack is more apparent than teal.

To begin with, the author's two articles on writing and the role of inspiration actually do find parallels in his fietional work in "O Anel de Contrabando," "A Linha Invisivel" and Uma Aventura Inquiletante. ${ }^{182}$. Furthermore, if one extends the role of inspiration to include creativity in the plastic arts, one finds that questions of this nature have arisen in the course of the main action of "Cinzas de Inceindio" and as a minor theme in A Escola do Pansiso. ${ }^{183}$

In addition, during this period Miguéis published a total of seven articles dealing with painting and drama, paincipally as a critic of those arts. ${ }^{184}$ These judgements have also had their counterparts in his fiction: witness his descriptions of the life of a family of theatrical people in A Escola do Paraiso and the narrator's fleeting comments on French and German architectural tendencies in "A Düsseldorf, num Pulo" and "Perdão, Fra Schwarz! "18s

However, the artist is a relatively rare sort of individual in the world at large and, true to the quality of verisimilitude which marks Miguéis' works, so it is in his prose fiction. Thus, it is entirely fitting that the major portion of the secondary category of his non-fiction, which deals mainly with literary and artistic questions, as we have seen, should find only slight owert echoes in Migueis' fiction, which after all represent some of the end-products of his artistic convictions. As for the remainder of this secondary category of non-fictional writings, it would seem that the subjects of these articles have simply not yet found their way into the author's fiction as explicit themes. Even these apparently negative correlations between his fiction and his non-fiction, then, are more apparent than real, especially when one considers that some of Migueis" fictional works remain to be published, or published in their entirety. In the last analysis, then, all of these differences and correlations between Miguéis' fietion and his non-fiction aze elucidative with regard to bis cosmovisalo, particularly in his role of a writer who comments on conditions he sees sround him: the author is after all free to choose which subjects he will treat, and how and when he does so.

In addition to commenting on the social and psychological problems he sees around him, however, an author may also speculate on other matters, such as the possibility of transcendental forces' operating on human life. Thus, it is important to note that there are reflections of such a possibility scattered here and there throughout Migueis works. Even the question of disease can be viewed in this light, as we have seen above. In many cases, it is presented in terms of a condition which Man cannot avoid, thus passing the control of that aspect of a persor's life over to Destiny or the supernatural, a force which has appeared as a theme in five of Miguéts' wotks of fiction, ${ }^{134}$ Finally, the transcendental forces at work on a person's life may give him knowledge of future events, not in any conscious way, but through premonition, which has appeared in six of the 


\section{An Onerview of Migutis' Prose Fiction.}

author's fictional works. ${ }^{1 * 7}$. Withal, these constitute an interesting and illuminating group of subsidiary themes, for they deepen our insights into Migueis' view of the wotld.

Another interesting aspect of the author's prose fiction is that the feminine character most closely related to the narrator of protagonist tends to be a native of the anbient culture. Thus, the $\mathbf{4 4}$ works of fiction under consideration, all of the principal female characters in Migueis "Portuguese" stories are Portuguese, all of those appearing in his "American" stories are American, Grandmother Ryala of "Os Desentendidos" is Galictan $^{135}$ and Grete of "Dezasseis Horas em Missfo Secreta" is German ${ }^{139}$ The situation with regard to the author's "Belgian" stories is a bit more complicated, but even Chire and Lèah are part of a French culture which is partially shared by French-speaking Belgians. ${ }^{190}$ All told, Vinogridova of "O Chapelinho Amarelo"191 is the only real exception to this phenomenon, inasmuch as she was from Eastem Europe, even though that story's protagonist meets her in Belgium. In any event, however, none of the major feminine characters in Miguéis' fictional works which are set entirely outside of Portugal are Portuguese. Thus, as a general rule Miguèis' major feminine characters reflect particular portions of the Earth - which itself was thought of as a feminine deity in entiquity.

In contrast, Miguéis' narrators of protagonists, who interestingly enough are all male, are almost all Portuguese. Only Professor Brown of "Enigmal, ${ }^{102}$ the nameless protagonist of "Dezasseis Horas em Missão Secreta," "103 the hobo in "A Esquina-do-Vento"194 and the subway sweeper of "Arroz do Ceu"10 s are clearly not Portuguese. The nationality of the protagonists of "O Anel de Contrabando" and " $O$ 'Crime Perfeito', 196 is not indicated, it is true, but the narrators or protagonists of the remaining thirty-eight fictional works are all Portuguese. Thus, when one remembers that nearly half of these fictional works are set outside of Portugal, it is evident that the author views the world primarily in terms of male Portuguese peregrination: a view which is both traditional in Portugal and is, in his case, particularly appropriate.

Last, this facet of Migueis writings leads us to another question, that of how personal is the author's viewpoint in his fictional works. As we have seen, there are numerous cortespondences between Miguéis' life and these works in terms of time, place, social and psychological content and, now, their narrators or protagonists. In addition, the narrators or protagonists in futly half of the author's fictional works are not named: ${ }^{197}$ a quality which heightens the empathic links between author and reader, by introducing a greater subjectivity into the various works. Furthermore, his narrators or protagonists in no less than twenty-six works are about as old as the author would have been at the time the stories are set. ${ }^{\prime 2}$. Last, and pertaps most revealing of all, the author limself is the narrator or protagonist for three short stories. ${ }^{100}$ In sam, it is evident that Miguetis' cosmovisio, as expressed in these 44 works of fiction, is a very personal one, indeed.

In conclusion, it is obvious that Jose Rodrigues Miguéis, in his non-fictional as well as his fictional works, has looked upon human existence as being marked by a great many unfortunate aspects of a social nature: as Renato Lima put it, "cedo me convenci de que a 
lei da vida é a injustiça- ${ }^{-200}$ However, as we have seen, primarily in his prose fiction, men are more than mere social, gregarious beings to Migueis, for as individuals they may be threatened both by society and by psychological aberrations within thernselves, In addition, however much men may pride themselves on their coutrol of their own destiny. the fact remains that they cannot control certain aspects of their lives, for there are forces at work on them which are lirgely ungovernable. However, like the many aspects of psychological abnormality treated by the author, these uncontrollable forces have also tended to be exemplified in his prose Detion rather than explored in a factual way in his non-fictional works,

Thus, it is in his prose fiction that the author has most extensively recoeded these problems for posterity and, mote importantly, presented them to his contemporaries for their consideration, for he is above all else a writer who is concerned with the present: the present, in which he hopes the seeds of future betterment may be sown. His view of the world as an artist includes reflections of the past, it is true, but the past is not romanticized. Rather, it is seen primarily in terms of the ills it harbored, many of which continue to the present day, even if in a different form. Thus, Migueis' retrospective view of life is far from being that of a saudosista, no matter how wermly nostalgic some of his fictional works may appear to be at first glance.

Furthermore, Miguéis' cosmovisāo, as expressed in his prose fiction, is a hịhly personalized one, in the sense that his own life flows in and out of his literary production, usually masked but occasionally mentioned overtly. The settings of the various works in time and place, for example, mirtor the twentieth-century, urban quality of his life to a great extent. Moreover, it seems evident that he has witnessed most of the social and psychological problems which form such an integral part of his fictional works' thematic content, either through random chance or detailed, methodical study and clinical observation. It is not lightly that he decries the existence of social injustices in the Old World and the New: he has seen them, presumably even suffered from some of them, on both sides of the Atlantic. It is not from a theoretical point of view that he deals with psychological aberrations, principally in his fictional works: he spent three years studying them on the postgraduate level, followed by forty-odd years of observing them. In short, it has not been out of literary expediency or partisan adherence to particular literary movements that Migué is has dealt with the pain and irony of Man's existence in his prose fiction, but out of a conviction arising from his view of the world, one which is dominated by an immense humanistic compassion towards the unfortunate, whoever and wherever they may be, while also exhibiting a great displeasure at the wastage of human resources and the selfishness of the powerful and the wealthy. Finally, Migueis' cosmovisao is not only one which is erudite yet down-to-earth, but is one which reflects the broad view of the world which has been a Portuguese trait for half a millennium.

Thus, even though he has spent more than half of his life outside of his native land, Miguéis has remained true to the best in the Portuguese nation while adhering to his own convictions that a writer "., deve ser, a um tempo, o mais conservador e o mais audacioso dos pioneiros de mundes interiores e sociais, a ponta que explora e sonda a realidade sempre erescente. . .

+201 For these reasons if for no others, then, the prose 
fiction of José Rodrigues Miguéis merits our closest attention in terms of time, place, and social, psychological and related problems, so that we may best understand what he has been saying, not only about Portugal and the Portuguese, but also about the rest of humanity.

\section{Dept of Foreign Languages and Literatures Northem Hilinois University nlinois, USA}

\section{NOTES}

${ }^{1}$ This paper was adapted from portions of my Ph.D. dissertation, Aspects of Time, Place and Themartic Content in the Prose Fiction of. Jont Rodrigues Mieneis as Indicstions of the Artit's Weltanzicht, The University of Wisconsin, Madison, Wiscontin, U.S.A., 1970. It was written under the dinction of Professar Jonge de Sena, to whom I am greatly indebted for his kind adviee and stimulation over a number of years. Any fauls, of course, are entirely my own.

${ }^{2}$ It is eossidered in this paper that the settings of Miguess' works of fletion with regard to dronological or calendar time and peographical place are of particular interest because of the author's wide travels and lengthy residence abroad. Similaly, it is presuned that the social and poychological problems observatile in these works give indications as to bow the author views the Bumin condition. For a brief resume of Mtgotis' first 73 years, see my paper, "A Thumbnail Sketch of the Life and Works of Josk Rodrigues Mizuéls," Proceedingz of the Pacific Northwest Council on Foreagn Languages, XXV (1) Literature and Linguistics 1974, pp. 35-39.

"José Rodrigues Mggaéis, "O Morgado de Pedra-Má" in Lénh e Outras Mistóriast, 4th ed. (Lisboa: Estudios Cor, 196\$), PD. 229-269.

"The following short stories are all by José Rodriques Migutis: "Morte de Homem" in Onde a Noite ne Acaba, 3rd ed. (Lisbon: Estúdios Cor, 1960), pp. 35-67; "Milagre de Joune," Seara Nove, No. 26, August-Septernber 1923, pp, 34-36; "A Sombr2," Sears Now, No, 112, December 22, 1927, Dp. 313-314; "Sob a Quuna Purificadora," Linhe Gentl (Loiria, Portugal), March 17, 1932, p. 2; and "Ite, Missa Est" in Gente de Terceiru Classe (Lisbon: Estúlios Cor, 1962), pp. 243-253,

${ }^{5}$ The following works are all by José Rodrigues Migaéis: Pazcad Feliz, 3td ed. (Lisbon: Estílios Cor, 1965): A Eroole do Panalso, 2nd ed. (Lisbon: Estúdios Cor, 1961); "Pouca Sorte com Barbeiros" in Liah e Outras Hatorias, 4th ed. (Lisboe: Estúdios Cor, 1968), pp. 91-113; "O Cosme de Riba-Douro" in Gente da Tereeina Closse (Lisbon: Estádios Cor, 1962), DD. 71-91; "Saudades pura a Dona Gencians" in Leinh e Ournat Historias, 40t ed, (Lisbon: Estúdilos Cor, 1968), pp. 197-227 and "Corno Éles se Amavanl ... (Conto Verídico de Amor e de Guerra)" which was publishod in five installments in Dibino de Noticias (New Bedford, Mass,) an the following dates: November 22, 1940, D. 2; November 23, 1940, D. 2; Nowember 25, 1940, p. 2; Navember 26, 1940, p. 2 and Nevember 27 . 1940 , p. 2, All five installnwats wete sipned "Leonarto Moreira",

"Jask Rodrigues Migueia, "Una Carreira Cortada" in Léan e Outras Higtóriar, 4th ed. (Lisbon: Estídios Cor, 1968), pa. 181-195.

The followine stort stories are all by Jose Rodrigues Miguéis: "Ponque te Calas, Amändio? ," Seava Nova, No. 1331-1 382, November-December 1960, pp. 338-341; "Os Desentendidos," Difrio de

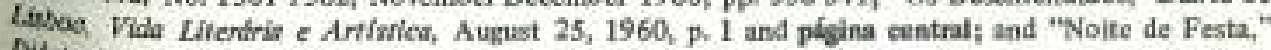
Dubro de Ltaboa, Surplemento do Namil, December 24, 1963, pp. 1 \& 2. 
"Jost Rodrigues Mieutis, "Entuemez Um," Divio de Lisbowe, Vide Lirenàrio e Arristice, April 9 1964, pp, 17819 and "A Linhul Invisivel" in Onde a Noüre se Acabs, 3rd ed. (Lisbon: Estútios Cor, $1960 \%, \mathrm{pp}, 119-171$.

9 José Rodrigues Miquáis, "O Chapelinho Amarelo" in Onde a Noóre se Acaba, 3rd ed, (Libon: Estúdios Cor, 1960), pp, 101-117.

10 José Rodrigues Migutis, "Penl55o, Frau Schwara!" in Gente da Terceira Classe (Lisbon: Estídios Cor, 1962), pp 177-187.

11 Tae following works are all by Jost Rodrigues Miguéis: "A Importảncia da Risca do Cabelo," is Lewh e Outrat Fistórias, 4th ed. (Lisbon: Estidjos Cor, 1968), pp. 161-179; 'Cinzas de Incesedio" in Onde a Noite se Acabo, 3nd ed.LLabon: Estidlos Cot, 1968), pp. 7-35; " Mucha Plata!'" in Gente dh Terceira Cleve (Lisbon: Estúdios Cor, 1962), pp. I51-157; "A Disseldorf, num Puls" and "Perdío, Frau Selwarz" both in Gente da Terceina Classe (Lisboa: Estúdios Cor, 1962), pp. 159-175 and 177-187 respectimelys Umas Aventurn Inquiefanfe, 2nd ed, (Lisbon: Estúdios Cor, 1963), tosd "Dezasseis Hons em Missio Secreta" in Leioh e Outras Histdriat, 4th ed. (Lishon: Estudios Cor, 1968). pp. 135-159.

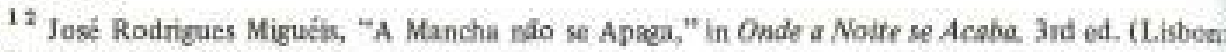
Estúdios Cor, 1960), pa. 69.99.

13 Jose Rodrigues Migutis, "O Acidente" in Onde a Noite se A cobs, 3rd ed. (Lisbon: Estádias Cor [960), pp. 235-259.

14 José Rodrigues Miguéis, "Primeiro Encontro com a Transcendente" and tsilwestre, os Seus Amores" both in Gente da Tereetra Classe (Lisbon: Estúdios Cot, 1962), pp. 189-201 and 203-221 respectively.

15 Josk Rodrigues Mequetis, "Uma Vagem na Noesa Terra" in Lèh e Oulnas Hisnorias, 4th ed (Lisbon: Estúdios Cor, 1968), pp. 37-63.

16 Jasé Rodrigues Miguéis, "Eniqgun!" in Onde a Noite se Acaba, 3rd ed. Alisbos: Estudios Cor, 1960), pp 7-33.

17 Jose Rodrigues Miguéis, "Gente ds Teroira Classe" in Gente da Terceind Chasse (Lisbon: Estúdios Cot, 1962), pp. 7-31.

Is The following works are sll by Josó Rodrigues Migueis: "O Vlajaste Clandestino" in Genfe da Tenceine Casse (Lisoont Estídios Cor, 1962), pp. 33-47; "O Natal do Dr. Crosby" in Lèah e Outrat Hisnories, 4th ed. (Liøoon: Estúdios Cor, 1968), pp. 65-89; "Beleza Onguthos" in Onde a Noite se Acahe, 3rd ed. (Lisbon: Estúdios Cor, 1960), pp. 261-271; "A Esquina-do-Vente" in Genfe ds Tenceiv Clesse (Lisbon: Estúdios Cor, 1962), pp, 93-111; "Natal Branco" and "Arroz do Ceu," botz in Gente do Tercetra Classe (Lisban: Estudios Cor, 1962), pp. 49-61 and 63-69, respoctively.

19 Jost Rodrigues Miguéls, "Pesdilo, Frau Schararl" and "O Cosme de Ribu-Douro" both in Gente de Terceirs Classe (Lisbon: Estudios Cor, 1962), pp. 137-1 BT and 71-91, respectively.

20 José Rodrigues Migutis, Um Homen Sami d Morte - Com Mcì Cara, 2 ad ed, (Lisbon: Estúdias Cor, 1965).

21 José Rodrigues Mfigutis, "Regresso a Cúpula da Pena" in Léah e Outras Hissóries, 4th of. (Lisbon: Estúdios Cor, 1968), Pp, 115-133.

22 Josb Rodrigues Migutis, "O Anel de Contrabando" and "O 'Crime Perfeite"," both in Gente do Terceira Classe (Lisbon: Estúdios Cor, 1962), pp. 113-127 and 129-149, respectively.

${ }^{23}$ José Rodrigues Mizuéis, "Lodo, ${ }^{\prime \prime} O$ Tempo e o Modo, No. 47, February 1967, pp. 223-229. Fo: I discussion of other aspects of setting and thematic content in this short story, sec my article. "Thematic Consistency in a New Mannet is Jose Rodrigues Miguébx' 'Lodo'," Luzo-Braziliow Resiew' Vol. 11, No, 2, Winter 1974, pp. 231-236. 
24 A. A. Mendilow, Time and the Novel (Londoa à Now York: Peter Nevill, 1952), ק. 104.

25 The followire works ure all by Jose Rodrigues Miguéis: Piscad Feliz, 3rd od. (Lisbon: Estudios 1965); $A$ Escola do Arraiso, 2nd ed. (Lisbon: Estúdion Cor, 1961): "A Linha Imvisível" and "O Acldente," both in Onde a Noite Se Acaba, 3rd ed. (Lisbon: Estudios Cot, 1960). pp. 119.171 and 135-159, respectively: "Uma Carreina Cortada" and "Saudades para a Dona Genctans," both in Lísh e avms Braborias, 4th ed, (Lisbon: Estudios Cor, 1968), pp. 181-195 and 197-227, respectwely; "Pimeiras Encostro com o Transcendente" and "Silvestre, os Seus Amores," both in Genie da Tercetra Crose (Lisbon: Extudios Cor, 1962), pp. 189-201 and 203-221; "Noite de Festa," Difrio de fishoe, Suplemento do Natri. December 24, 1963, pp, 1 \& 2; "Sob a Chura Ruriflcadora," Linha Gend' (Leiriz, Portugal), March 17, 1932, p. 2; "Porque te Calas, Amindio?," Seara Nonu, Na. 1381-1382, November-December 1960, pD. 338-341; 't'Entremez Um," Diario de Liabos, Vido Jithendris e Artistica, Aprie 9, 1964, pp, 17 \& 19; "Regresso à Cúpula da Pena" in Lámh e Outhus Fintorios, 4th od. (Lisbon: Estúdios Cor, 1968), p. 115-133; and "Lodo," O Tempo e o Modo, No. 47, Fosnury 1967, pp 223-229.

76. The following short stories are all by Josê Rodrienss Migutis: "A Mancha nâto se Apaga" in Onde a Noive se Acsha, 3rd ed. (Lishoin: Estudios Cor, 1960), pp, 69-99; "Uma Viagem na Nossa Terts" in Lesh e Outras Filstorias, 4th ed. (Lisoon: Estudios Cor, 1968), pp, 37.63 and "Como Êles se Amuvam! ... (Conto Verílico de Amor e de Gerra)" which was published in five installments in Dírio de Noricins (New Bedford, Nass) on the following dates: November 22, 1940, p. 2; November 23, 1940, p. 2; November 25, 1940, p. 2; November 26, 1940, p. 2; and Noverber 27, 1940, p. 2.

27 The following short stories are al by José Rodrigues Migucist "Milagre de Joane," Seara Nova, No. 26, Aurust-September 1923, pp 34-36; "A Sombra," Sear Nova, No. 112, December 22, 1927 , ta 313.314;"'-Ite, Missa Est"," in Gente do Terceire Clsuse (Lisbon: Estúdios Cor, 1962), pp. 243-253; "Morte de Homem" in Onde a Noite se Acubs, 3rd ed. (Lisbon: Estudios Cor, 1960), pp. 35-67; and "O Morgado de Pedn-Mi" in Läeh e Overas Histórier, 4th ed. (Lisbon: Estúdios Cor, 1968). Ip 229.269.

28 Jose Rodrieues Migués, "Os Desentendidos" Dlsrio de Lisboa, Vada Litrentria e Artistica, August 25,1960, p. 1 and pigina central,

${ }^{20}$ The following works are all by José Rodrigues Miguéis: "O Chapelinbo Amareto" and "Cinzas de Invíndio," both in Onde a Noire se Acabe, 3nd ed. (Lisben: Estílios Cor, 1960), pp. 101-117 and 173-233, respectively; "Mucha Platal," in Genle da Terceina Classe (Lisbon: Estridios Cor, 1962). IP 151-157; Uma Aventura Inquietente, 2nd ed. (Liabon: Estúdios Cor, 1963); "Léah" and "A Importincia da Risca do Cabclo," both in Lerah e Ouras Inistórias, 4th ed, (Lisboni Estidios Cor, 1968). pp 7.35 and 161-179, respectively.

30 The following short stories are all by José Rodriesues Migubis: "A Düsseddorf, num Pulo" and "Rendlio, Frau Schwarzl" both in Gente de Tenceira Classe (Lisbon: Estudios Cor, 1962), Pp. 159.175 and 177-187, respectively; and "Devasseis Floras em Missajo Secreta" is Lelah e Outras Histdrigs, 4th d. (Lisbon: Estúdios Cor, 1968), pp. 135-159.

31 José Rodrigues Miguéts, "Gente da Teneqira Casce" in Gente de Terceiru Classe (Lisbont Pstüdios Cot, 1962), pp. 7-31.

32 José Rodrigues Migućis, "Enzumal" in Onde a Noile se Acaka, 3nd ed. (Lisbons Estúdios Cos, 1960), Da. $7-33$.

${ }^{33}$ The following short stories are all by Jose Rodrigues Miguéis. The four stories immedlately followirg are all from Gente dr Terceint Clesse (Lisbon: Estúdios Cot, 1962): "O vime Perfeito" w 129-149; "O And do Contrabando," pp. 113-127; "Arroz do C6u," pp. 63-69 and "Nital Hrasco," pp. 49-61. "O Natal do Dr. Crosby." in Lebh e Outnas Historiar, 4th ed. (Lisbon: Estuidios Cor, 1968), pp. 65-89; "Beleza Orguthosa," in Onde a Notte se Acahe, 3rd ed. (Lisbon: Estúdius Cor, 1960), Dp. 261-271; "O Cosme de Riba-Douro," in Gente da Tereeina Casse (Lisbon: Estúdios Cor, 1962). Dp. 21-91: "A Esquina-do Yento" and "O Viajante Clandestino," both in Gerate da Terceint Close (Lisbon: Estudjos Cor, 1962), pp. 93,111 and 33-47, respectively. 
34 Jose Rodrigues Miguéis, "Pouca Sorte com Barbeinos," in Lên e Oubras Histobiss, 4th ed. (Lisboa: Estúdios Cor, 1968), pp. 91-113.

${ }^{35}$ Robert Liddell, $A$ Thearlse on the Novel (London: Jonathan Cape, 1947), pp. 112-128,

36 Jose Rodrigues Miguctis, "A Esquina-do-Vento," in Gente de Terceina Clarse (Lisbon: Estúdios $\mathrm{Cor}_{n}$ 1962), Pp. 93.111.

37 Miguels' article on this subject was: "Consideraçots à Margem dn Laberdade e da Autoridade on Ensino," A Repiblice (Lisbon), June 29, 1932, p. 2. This theme appears in Ume Aventure Inquietante, 2nd ed, (Lisbon: Estúdios Cor, 1963), pp. 40 \& 208.

38 Josḱ Roürigues Miguéis, "Sobre as Acontecimentos e o Progresso," Seara Nond. No. I68, July 4, 1929, Dp. 371-373.

39 Jose Rodrigoes Meieukis" article on this subject was: "Crónica - E Proibido Apontar," Sésene Nowa, No. 131, October 4, 1928, p, 206. This theme appears in: "Entremer Um," Difrio de Lisboe, Vha Literinia e Artistice, April 9, 1964, f. 19; "Pendllo, Frau Schwarz!" in Gente da Terceire Cagre (Libboa: Estudisos Cor, 1962), p. 186 and "A Linhs liwisivel" in Onde a Nolve se Acaha, 3rd ed. (Lisbon: Estídios Cot, 1960), po. 130-132.

40 José Rodrigues Miguéis" article on this subject was: "Poeira da Rua: O Meu Amigo Radical," A Republice (Lisbon), June 19, 1923, p. L. This theme appears in " Mucha Platal" and "A Dlisseldorf, num Pulo," both in Gente da Terceìn Casse (Lisbon: Estúdios Cor, 1962). pp. 155-156 and 166, 171 respectively.

41 José Rodrigues Miguéis' article on this subject was: "Leituras e Bibliotecas," O Disbo (Lisbon), September 23, 1934, p. 2. This theme appears in A Escole do Ranaiso, 2 nd ed. (Lisbon: Estílios Cor, 1961), p. 211.

42 José Rodrigues Mieuấis, "Portueal é Ruco: Mas Nós Nžo o Sabemos!," A Repúblies (Lisbon), A peil 1, 1923, p. 1.

43 Joxé Rodrigues Miquatis" artide on this subject was! "Quem Paga é o "Bey" de Tanis," Seare Nova, No, 1000-7, October 26, 1946, pp. 188-191. This theme sppears in "'Mucha Plata' "in Gente ds Terceirn Classe (Lisbon: Estudios Cot, 1962), p. 153.

44 Josí Rodrigues Mieuếs, "Os Nossos Organismos Sociais: Instituto de Orientaçlio Profissional 'Maria Lusia Basbosa de Carraibo'," Seare Now, No. 114, January 26, 1928, pp. 354-356.

45 Jaxi Rodrigues Miquéis, "Em Louvot de Limpeza," Searu Nova, No. 65, Decembet 19, 1925, pp. 96-97.

46 José Rodrigues Miguéls, 'Ssudades para a Dona Gencians," in Leth e Outras Hastodian, 4 th ed. (Lisboa: Estúdios Cor, 1968), pp. 210, 218, 2208 221; A Escola do Auratso, 2nd ed. (Lisbon: Estúdios Cor, 1961). pp. 69, 125, 260, 271-272 \& 280; "Primeito Encontro com o Transcendente," in Gente de Terceina Clase (Lisbon: Estudios Cor, 1962), p. 187; "Sob a Cauva Purificadora," Linhe Geral (Leirla, Portugul), March 17, 1932, p. 2 and "Porque te Calas, Amaindio?," Serana Nove. No, 1381-1382, November-December 1960, p. 340 .

47 José Rodrigues Meuéis, "Filosofia das Cacarolas," $O$ Dabo (Lisbon), October 14, 1934, p. 8.

48 All the following works are by Jose Rodrigues Mgzuéis: "Beleza Orgulhosa," in Onde a Noire Ne Acaba, 3rd ed. (Lisboa: Estúltios Cor, 1960); Umi Aventung Inquietante, 2nd ed. (Lisbon: Estúdios Cot, 1963). p. 34; and "A Mancha nāo se Apaga" in Onde a Noire se Acabe, 3rd ed. fLisbon: Estudios Cot, $1960)$, D. 81.

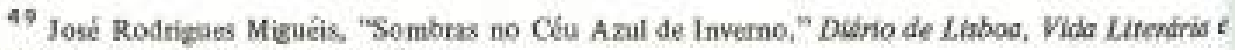
Arriatica, January 12,1968 , pp. 1 \& 11 .

50 José Rodrigues Miguéis, "Como se Ams na América," Ver e Crer, No, 24, March 1947. pa $33-41$. 
51 This thense appeas in the following short stories by José Rodrigues Miguéis "Beleza Ongallicsi," in Onde a Noite se Acaba, 3nd ed. (Lisbon: Estudios Cor, 1960), pp, 267-269; "A Esuina-do-Vento" and 'O "Crime Perfeito'," both in Gente de Tercetra Classe fLisbon: Estudios Cor, 1962), Pp, 109 and $132,139,144-145$ respectively.

32. The following works are all by Joob Rodriguet Miguéis: "Cinzas de Incêndio" and "Beleza Orgallioss," both in Onde a Noire se Acabs, 3rd ed. (Lishon: Estridics Cor, 1960). The following sbort tories ane all from Letah e Outras Histonias, 4th ed. (Lisbon: Estudios Cos, 1968), Each story will be follawed by the appropriate page numbers in the volume, as nocessary. They are: "Lfah," pp. 18ff.; "Fouca Sorte com Barbeiros," pp. 98-99; "Regresso ì Cúpala de Pess," pp. 132-133; "Dezasseis Flerssem Missio Sotreta," pp. 147-154; "A Importância da Risca do Cabelo;" "Uma Carreira Cortada;" "Sipdades para a Dora Genciana," pp. 209,210, 214, 219 \& 227. Uma Aventure Inquietante, 2nd ed. (Lisbon: Estúdios Cor, 1963). pp. 37, 58, 98 \& 202; A Ercole do Paralso, 2nd ed. (Lishon: Estudios Cor, 1961), pp. 48-55, 59, 90, 242 \& 297; "Silvestue, os Seus Amores," in Gente da Tenceins Clesee (Lisbon: Estúdios Cor, 1962), pp. 221-222; “Como Eles se Amavaml. . . (Conto Veridico de Amor c de Guerra)" (Pt. II), Diśrio de Norfeies (New Bedford, Mass.), November 23, 1940, p. 2; and "Porque se Clas, Amindio? " Seara Nora, No. 1381-1382, November-December 1960, pp, 338-339.

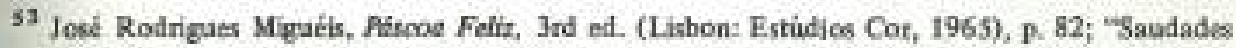
para a Dose Genciana," in Leoh e Oubra Firtovias, 4th ed, (Lisbont Estudios Cor, 1968), p. 205; A Excola do Furalso, 2nd ed. (Lisbon: Estúdios Cor, 1961), pp. 45-46, 72 \& 90; "Os Desentendidos," Disirio de Lisbod, Vida Literíla e Arristica, August 25, 1960, p. 1 and pígina central.

14 José Roćrigues Mizucis, "Notas Sobbre un Conceito Inofensivo," Linhs Genal (Leiria, Portugal), December 31, 1931, pp, 4 \& 6 and "A Exposiç̃o dum Pensamento: Os Homens têm Sede de Solidăo, de Vida Própria, de Autonomia Interior," A Repáblice (Lisbon), June 24, 1932, p. 5.

ss In the following three works by Josk Rodrigues Miguéis this theme is of major importance: Ume Avenhure Inquietrente, 2nd ed. (Lisbon: Estúdics Cor, 1963), 98-99, 103, 145 \& 168; "0 Cosme de Riloe-Douro," in Gente da Tercetru Carse (Lisbon: Estúdios Cor, 1962), p. 78; and "Bejera Onzulhosa," in Onde a Noite se Acaha, 3nd ed. (Lisbon: Estidios Cor, 1960), P. 266. In the following twort stories this theme is of minot importance: "O Natal do Dr. Crosby," in Lebh e Outras Histdries, 4t ed. (Lisbon: Estúdios Cor, 1968), pp 72 \& 75; "Saudades para a Dona Genciana," in Ledah $e$ Oubra Fifsróriar, 4th ed. (Lisbon: Estídios Cor, 1968), p. 203; and "A Dässeldarf, mum Pulo," in Gente da Tenceina Clene (Lisbon: Estudios Cos, 1962), p. 166.

56 José Rodrigaes Miguels, "Crónica da Cadade: A Margem," A Repibilica (Lisbon), May 17, 1923, A. 2 [Signed "R.M."]; and "Poeira ds Rua: Felo Rei," A República (Lisbon), June S, 1923, p. 1.

59 In the following four works by Josk Rodrigues Migueis this theme is of major importance: "A Linha Invisirel," in Onde a Noile ae Acabe, 3nd ed. (Lisbon: Estúdios Cor, 1960), pg. 167-168; "Dezarseis Horas em Missio Secreta," in Léwh e Ouanas Hirabries 4th ed. (Lisbon: Estadios Cor, 1968), pp. 137-138; A Ercole do Panalso, 2nd ed. (Lisbon: Estíbdios Cor, 1961), pp. 124, 172-174, $281,306-313,320,322-323,325,338-339$; and "A Disseidorf, num Pulo," in Gente de Tereeha Crsse (Lisbon: Estudios Cor, 1962), p. 186. In the following works this theme is of minor importanee: "Pouca Sorte com Barbeiros" and "Saudades para a Dona Genciana," both in Léah e Oubas Hitórias 4th ed. (Lisbon: Estúdios Cot, 1968), pp. 96-97 and 200-201, 213-217, respectively; and Ume Arentura Inquietante, 2nd ed. (Lisbon: Estúdios Cor, 1963), p. 128.

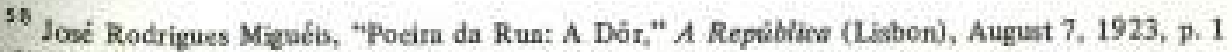
and Um Homem Sorri d Morte - Com Meia Cara, 2nd ed, (Lisbon! Estidios Cor, 1965). 
59 In the following works by Joxé Rodrirues Migueis this theme is of major importancen Päroug Feiliz, 3rd ed. (Lisbon: Estúdios Cor, 1965), pp. 36 \& 38;"Uma Carreira Cortada," "Saudades pan a Dona Genciana" and "O Morgado de Pedn-Mi," all three is Liah e Ow prar Firróniar, 4th ed. ALisbon: Estútion Cor, 1968), Pp. 181-195; 197-227; and 237, 241-269, respectively; and "Ponque te Cass, Amàndio? ," Sedru Nowa, No. 1381-1382, November-December 1960, Pp. 338-341. In the following works this theme is of anly minor importance: "Norte de Homem," in Onde a Noite se Acaha, 3nd ed. (Lisbon: Pstudios Cor, 1960), D. 42; Ume Aventung Inquiferante, 2nd ed. (Lisbon: Estídios Cor. 1963), Dp. 50, 102, 161-173 \& 219; A Escola do Pandisa, 2nd ed. (Lisbon: Estúdios Cor, 1961), pp. 43, 57, 81, 106-107, 243-244, 257, 260, 297-299, 313, 317, 334, 354, 361, 364-365; "Gente dit Teroeira Classe" and "O "Crime Perfeito"," both in Gente da Tenceina Classe (Lisbon: Estúdion Coit, 1962), pp 14, 18-20, 27-29 and 139-140, respectively.

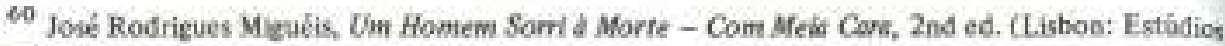
Cor, 1965).

61 Jow Rodrigaes Miguéts, Pincos Feliz, 3rd ed. (Lisbon: Estúdios Cor, 1965), p. 38 and "Morte de Homem," in Onde a Noire se Acaba, 3rd ed, (Lisbon; Extúdios Cor, 1960), p. 42.

62 José Rodrigues Miguèis, A Excoli do Parafisa, 2nd ęd. (Lisbon: Estúdios Cor, 1961), pp, 41 \& 150

${ }^{63}$ In the following two short stories this theme is of major importance: "A Sombra," Seara Nova, No. 112, December 22, 1927, Pp. 313-314 and "Os Desentendidos," Didrio de Lisboe, Vide Literdrir e Artistica, August 25, 1960, 17-18. In the following two works this theme is of miner importince: "Léah." in Lénh e Outras Uistórias, 4th ed. (Lisbon: Estüdios Cor, 1968), p. 35 and A Ercole do Faraiso, 2nd ed. (Lisbon: Estúdios Cat, 1961), pp. 299.301.

64 In the following two short stories by Josk Rodrigues Megueis this thene is of major importance: "O Acidente," in Onde a Noite se Acsha, 3rd ed. (Likbon: Estudios Cor, 1960), 0p. 235-259 and "Noite de Festa," Difino de Lisboa, Siriemento do Natat, Decenbet 24, 1963, pp, 1 \& 2 . In the following work this theme is only of minor impertance: $A$ Escold do Purstsa, 2nd of, (Lisbon: Estúdios Cor, 1961), pp. 9.14, 63, 193-196.

${ }^{65}$ In the followine work by José Rodrigues Migaéis this theme is of rolatively major importance: A Ercole do Panotso 2nd ed. (Lisbon: Estúdios Cor, 1961), pp. 64, 196-203.

66 Josó Rodrigues Mfigutis, "Na Ordem do Dis," Seare Nova, No. 53, September 15, 1925, p. 9 ? [Sizned "R.M."], and "Independentes e Filiados," Seara Nova, No. 53, September 15, 1925, p. 98 [signed "R.M."]

${ }^{67}$ Josć Rodrigues Miguểs, "Potira đa Rua: Diglomatas," A Repáblica (Lisbon). June 12, 1923, p. I and "Os Trabalhadores e a Paz," Seare Now, No. 56, Oetober 17, 1925, p. 158.

68 José Rodrigues Miguéis, "A Crise e a Proletarizaçito das Classes Médias," A República (Lisbon). August 6, 1932, p. 5 and "Da Fatalidade à Consciência," Dufrlo de Linhor, September 13, 1963, pp. 1 8.9.

69 Joșé Rodrigues Miguéis, "Metrópolia; ou a Morte do Progresso," A Naticha (Liabon), Apnil 10, 1928, p. 4 and "O Paraíso das Objectos," Dibrio de Lisbov, Vida Literiria e Artistica, August 1, 1963, pQ. 17819 .

${ }^{70}$ In the following three works by José Rodrigues Miguéis this therce is of relatively majol importance: "Saudades para a Dona Genciana," in Llah e Oubas Hiatorias, 4th ed. (Lisboa: Estúdios Cut, 1968), pp. 227-228; "A Esquina-do-Vente" aod "O 'Crime Perfejto'," in Gente de Terceina Clase (Lisbon: Estúdios Cor, 1962), pp. 93-111 and 108, respectively. In the shart story which follows, this theme is only of minot importance: "Natal Brance," Gente da Terceira Classe (Lisbon: Estúdios Cos, 19627, p. 56. 
7 José Rodrigues Migufis' articles on this subject were: "Literatura Expatriada," Gazefa Mirsical, 2nd Serses, No. 85, April 1958, pp. 64-65 and "O Ofício do Escritor: Um Inquérito da Gezeta: Depoimento de Jos Rodrigues Migufis," Gazera Afusical, 2nd Series, No. 100-101, July-August 1959, pP. 341-342. This therese appears in: "Silvestre, os Seus Amores," in Gente da Terceirs Clerre (Lisbon: Estídios Cor, 1962), p. 207.

72 Jasé Rodrigues Miguetis published the following articles on thir topic: "O Problema do Inquilinato: Tal Como o Ve o Senhor Ministro da Justiça," A Repüblica (Lisbon). May 22, 1923, p. 1; "O Problersa do Inquiniazto: Apreciado pelo St. Dr. Azeredo Perdigäo, "A Repábica, June 7, 1923, Pa 182 ; and "O Problema do Inquilinato..." A Republics, June 8, 1923, Pp. 1 \& 2.

73 José Rodrigues Migeáis" three articles on this subject were: "A Cidade e os Seas Factores Comuns: Onde se Comseça num Artizo e se Acaba numa Crónica," A Repúblice (Lisbon), July 2, 1932, A. 4; "As Ruínas do Coliseu," Seura Nova, No. 136, November 8, 1928, pp. 315-317 and "Comentários: As Árvores," O Globo (Lisbon), November 25, 1933, p. 1 [Unsigned] This theme appears in

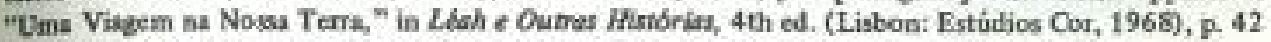
ind "Parque te Calas, A mindio? ," Sean Nona, No. 1381-1382, November December 1960, 1. 339.

74 Jost Radrigues Migaeis" three articles on this subject were: "X Margem dum Masifesto," Seara Novs, No. 142, December 20, 1928, pp. 422-423; "Hesust - O Rei da Imprensa," O Diabo (Lisbon). December 29, 1935, pp, 1 \& 8 and "Ainda Camōes Adulterado,", Didrio de Notfelas (New Bedford, Mass.). August 16, 1956, p. 1. This theme appears as a major one in: Uma Avernure lnquietante, 2nd ed. (Lsbon: Estúdios Cor, 1963), Pp. 28-29, 41, 145 and 248; and "Entremez Uns," Ditrio de Lisboa, Wide Litheninit e Artistice, April 9, 1964, p. 19.

Is In the following works by José Rodrigues Miguets this theme is of minor importance: "Beleza Orgulhose," in Onde a Noite se Acabe, 3nd ed. (Lisbon: Fstúdios Cor, 1960), p. 263 and A Ercole do Puruiso, 2nd ed. (Lisbon: Estúdios Cor, 1961), pp. 168, 192 \& 199.

76 José Rodrigues Migués published the following articles on this subject: "Serviços Públibos: 0 St. Dr. Balbino Rego Diz-nos o que Sío os Serviços Antropométricos, " A República (Lisbon), June 23, 1923, p. 1. "Rofexōes de um Burguéı (II) - Punir," Sarra Now, No. 113, Jamaary 12, 1928. pp. 326-327 and "Reflexdes Söbre o Crime e o Cartigo," A República (Lishon), July 18, 1932, p 5.

77 In the following work by Jose Rodrigues Migutis this theme is of major inportance: Uma Aventura Inquietants. 2nd ed. (Lisbon: Estúdio Cot, 1963), pp. 23, 27-28, 49, 60-61, 65-66, 84-93, $114,197,221,223$ \& 251. In the next work it is only of minor importance: A Ercole do Purafso, 2nd ed. (Liboon: Estedios Cor, 1961), pp. 122-123.

73 In the following works by José Rodrigues Mizuéis this theme is of major inportance: Pdrcod Felvz, 3rd ed. (Lisbon: Estúdios Cor, 1965), "Morte de Homem" and "Beleza Orgulhosz," in Onde a Woite re Acaba, 3rd ed, (Lisbon: Estúdios Cor, 1960), Pp. 35.67 and 264-271, respectively; "Dezasseis Boras em Missio Secreta" and "O Morgado de Pedra-Mh́," both in Labh e Oufras Historias, 4th ed. (Lisbon: Estádios Cor, 1968), pp. 155 and 229-269; Ume Arentum Inquichante, 2ad ed. (Lisbon: Estadios Cor, 1963), pp. 18.25, 27, 71, 99.100, 210, 222, 232, \&.254; "O Anel de Contrabando," "O "Crine Perfeito"," and "Perdito, Frau Schwarz!," all throe in Gente da Tenceine Corse, (Lisbon: Estud bs Cor, 1962), pp. 115 \& 128; 129-149 and 177-187, respectively.

79

This thene is of minor importance in the followine works by Josk Rodrigues Migutis: "Poues. Sorte com Babeiros" in Leoh e Oumas Hiandrias, 4th ed, (Libbon: Estudios Cor, 1968), p. 101; A Eqcolit do Paralso, 2nd ed. (Lisbon, Estiutios Cor, 1961), pp. 181, 187-191, 202-203, 238, 256, 322, 329-330, 372-375; "Gente da Tereeira Clasve," "O Viajante Candestino," \& "O Cosme de Pjha-Douro," all three in Gente da Terceino Cosse, (Lisbon: Estúdios Cor, 1962), pp. 22; 39; and 79, $81-82$.

Bo Jose Rodrigues Mequêis" three articles on this topic were: "Poein da Rua: Camb̋es," A Repuiblica (Lisbon), June 10, 1923, p. 1; "A Lourinha," in Guie de Portugal, edited by Raúl Proença, et at. (Lisbon: Biblioteca Nacional de Lisboa, 1927), II, 559-565 and "Os Acordes Dissonantes," Seare Nose, No, 1440, Octobet 1965, pp. 309 \& 311. 
${ }^{81}$ José Rodrigues Mtiguéis, "Uma Viggem na Nassa Terrs," in Llah e Owtras Históniar, 4th of (Libon: Estudios Cor, 1968), p. 49; "Gente da Terceira Classe," and "A Dilsseldorf, num Pulo," both in Gente da Tenceins Clarse (Liston: Estúdios Cor, 1962), pp. 25 and 163, respectively.

82 José Rodrigues Miguéis published the following on this subject: "Roeira da Rua: Lixo Sagrade, A Repábbca (Lisboa), May 30, 1923, p. 1: "A Política, o Especticulo e a Fé, "Seare Now, No, 176 Augest 27, 1929, po. 120-122; "Probleanas Sociais: O Direito de Amar e co Deveres que te

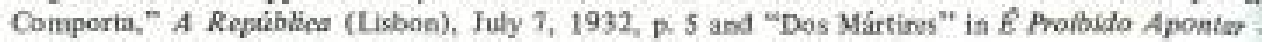
Reflexder de um Eiurgaés - I (Lisbon; Estúdios Cor, 1964), pp. 199-210.

83 In the following short stories by José Rodrigues Miguéis this themse is of major importance "Wite, Missa Esr"," in Gente do Tenceina Casse (Lisbont Estudios Cor, 1962), pp. 251-253; "Como Fle se Amakaml ... (Conto Verídico de Amor e de Gaerra) (Pr. III), Dísio de Noricint (New Bedford Mass), Noveraber 25, 1940, p. 2 [Signed "Leonardo Moreira"] and "Millagre de Joane," Seara Nowe, No. 26, August-Septenber 1923, pp. 34-36.

\$4 In the followiag short stories by José Rodrigues Mizuéis this theme is relatively important "Arroz de Céu," in Gente da Tereeinu Classe (Lisbonn: Estúdios Cor, 1962), p. 67 and "Dezasseis Hatas em Massio Secreta," in Léth e Outras Histórias, 4th ed. (Lisbon: Estódios Cor, 1968), pp, 143-146.

85 This theme is of minor importance in the following works by Josh Rodrigaes Miguéis: * $A$ Importâncja da Risca do Cabelo" and "O Morgado de Pedra-Má," both in Leath e Ouma Harórias, 4te ed. (Labon: Estúdios Cor, 1968), pp, 172 and 250-256, respectively; Pfracos Felit, 3rd ed. (Lisbon: Extúdios Cor, 1965), pp.11, 17, \& 38; "Gente da Tercein Casse," in Gente da Terceire Clarne (Lisbon: Estódios Cor, 1962), p. 29; A Escold do Funiiso, 2nd ed. (Lisbon: Estúdios Cor, 1961), pp. 62, 222-223, 326 \& 338; and "Entremez Um," Didrio de Lisboe, Vida Literíria e Artistica Apeil 9, 1964, pp: $17 \& 19$.

B6 Josk Rodrigues Migueis published the following articles on this swbect: "Hora de Renovo," $O$ Sol (Beja), April 21, 1921, p. 1; "Poeies da Rua: A Guerra e a Paz," A República (Lisbon), Juno T, 1923. p. 1; "A Paz - Casus Belli," Seurs Nowa, No. 184, October 24, 1929, pp. 248-249; "Firmati 1 Paz...., Limha Gerd (Leiria, Portuga), March 10, 1932, p. 4 and "Heróis e Condeasdos," O Drabo (Lisbon), Febraary 17, 1935, pp. $1 \& 6$.

${ }^{87}$ In the three following short stories by Jose Rodrigues Migueis this theme is of maju importanoe: "Come Eles se Ammaml.... (Conto Verídico de Amor e de Guerra)." published in five install mients in the Dierio de Norfeks (New Bedford, Mass.) on: November 22, 1940, p. 2; November 23, 1940, p. 2; November 25, 1940, p. 2; November 26, 1940, D. 2; and November 27. 1940, p. 2 [Signed "Leonardo Morcina" f, "O Cosme de Riba-Douro," and "A Delsseldorf, mum Pulo," both in Gente do Tenceire Classe (Lisbon: Estúdios Cor, 1962) Pp. 71-91 and 162, 165, respectively. In the following works this theme is only of minor importance: "Natal Hranco," in Gente de Terceira Clase (Lisbon: Estúdios Cor, 1962), p. 59, 60; "O Mosado ds Pedra-Mi," in Lesh e Oubras Hirtórias, 4th ed. (Lisbon: Estúdios Cor, 1968), p. 237; A Escola do Paraisa, 2nd ad. (Lisbon: Estúdios Cor, 196t). pp. 20-21, 92, 112, 128-130, 240, 338-339; Uma Aventura Jrquietante, 2nd ed. (Lisbon: Estúdics Cor, 1963), po, 50-51, 186, 199-200, 201, $207 \& 230 ;$ and "Lodo," O Tempo e o Modo, Na. 47. February 1967, p, 223.

an Josê Rodrigres Miguéis published the following articles on this subject: "Colsas deste Mundo... O Eterno Xadrez. Internaconal - Os Políticos e Mussolinj - Coolidge, o Silencioso," A Repribriod (Lisbon), August 15, 1923, p. I; "Os Estados-Unidos Europeus," Seara Now, Ne. 96, Algust 12, 1926 pp. 466-470; "Weimar - Onze de Aposto de 1919," Sewa Nova, Ne. 173, August 8, 1929, p. 72 [Signed "R.M."]; "A Pormbs de Paz na Gaiols de Arame Farpado," A Repúblice (Lisbon), July 25, 1932, P. 4; "Crepisculo da Europa," [Editorial] $O$ Grobo (Lisbos). November 25, 1933, pp, 13, [Unskened]; "Eleipoóes," O Globv, November 25, 1933, p. 6 [Unsigned] "A Teoria da Brasilidade," Dusrio de Notfciss (New Bcdford, Mass.). Dotember 21, 1940, pp, I \& 2 and "Dos Imígenes ded Brasi," Nonte (New York). July 1944 


\section{Ad Onenview of Migueis "Prose Ficrion ...}

1\% The following warks are alt by José Rodrigues Migneis: "Cinzas de Incéndio," in Onde a Natze Acabo, 3rd ed. (Lisbon: Estídios Cor, 1960), Fp. 173.233; "O Cosme de Riba-Douro" and "Perdăo, Scbuarzl," both in Gente de Terceina Clarse (Lisbon: Estudion Cor, 1962), pp. 83-91 and $174-180,182,184,186$, respectively.

${ }^{\circ}$ The following works are all by Josó Rodrigues Mequéis: "Enigmal" and "A Linha Irvisilvel," reth in Onde a Noire se Acahd, 3rd ed. (Lisbon: Estúdios Cor, 1960), pp. 14 and 131, respectively;

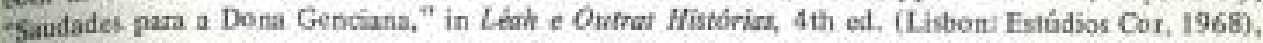
pr. 203-205; Uma Aventura Inquietanie, 2nd ad. (Lisbon: Estódios Cor, 1963), pp. 20, 28, 40, 44, 191, 206-207, 260 \& 263; A Escole do Furaiso, 2nd ud. (Lisbon: Estúctios Cor, 1961), pp. 172 \& 206; and "'Macha Platal?" in Gente de Tereetira Classe (Lisbon: Estudioa Cor, 1962), pp, 155-156.

91 The following two short steries afe by Joxé Rodtigues Mrgueits: "A Desseldorf, num Pulo," in Gerie de Terceiva Carite (Lisbon: Eastúdios Cor, 1962), pp. 161, 165-167 \& 175; and "Entremex. Um,"

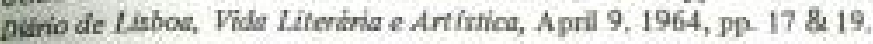

91 Jose Rodrigues Miguéts" artieles on thes sabject were: "Poeira Aa Ruar Touros de Morte," A Repablica (Lishon), May 20, 1923, D. 2; "Poein da Rua: Espera đe Toiros," A República, June 16, 1923. p. 1; "A Margem do Sekcentismo: Piblica Explicap̧o Sobre um Libelo," Seang Nona, No, 88, May 20, 1926, pp. 303-310; "Umsa Ilusio que se Deufaz," Seara Nowr, No. 145, January 10, 1929, IP. 3-5; "Ssbre os Fins a a Corgem nos Meios de Actuar (I)," Seeru Nowa, No, 220, September 18, 1930, pp, 58-61 [Signed "R.M."] "Sotre os Fins e a Congem nos Meios de Actan (II)," Sean Nove,

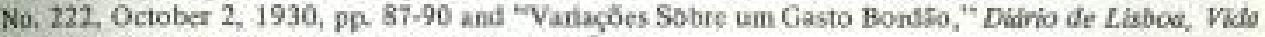
Liteniris e. Artistiod, Novumber 7, 1963, pp. 17 \& 19.

93 The two following works are by José Rodrigues Stigutis: A Escola do Puruíso, Znd ed. (Lisbon:

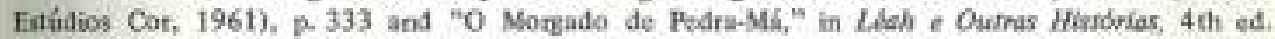
(Lishon: Estridjos Cor, 1968), p. 243.

94 Mizuéts published twelve articles on this subject. José Rodrigraes Miguêts et at, "Estatutos do ferutgimento Nacional," $O$ Sol (Beja), May 14 1921, pp. 2 \& 3 and Jood Rodrigues Miguéis et al., Aptio in Naçĭo," Seara Novs, No. 21, February-March 1923, pa. 129.135. Sfiguéts also publisbed the following: "O Pensamento Republicano e a Geraçâo Nova," O Século (Lişbon), February 29, 1924. R I; "A Geraç̃o Nova," A Repuiblion (Lisbon), Manch 1, 1924, p. I; "Uniijo da Mocidade Republicana," Seara Nova, No. 32, March 1. 1924, pp. 159-161; "Poliftica. Partamento e Competëncia," Seara Nore, No. 39, November-Decerober, 1924, pp. 55-56; "RevisĪo Constitucional," Seara Nove, No. 49. July is, 1925, pp. 16-17 [Signed "R.M."]; "Salvemes o Parianentismo," Sevra Nove, No. 70, January 16, 1926, pp. 185-187; "A Representaçilo Proporclopal," Sewa Nowa, No. 79, March 20, 1926, pp. 126-126; "Reflexôes," Seana Nove, No. 101, June 30, 1927, pp. 83-85; "Uma Carta," Seara Nove, No. 235, Jamary 22, 1931, pp. 296.299; and "A Merwagem du Juventude," Glidio (Lisbon), January $31,1935,0 p, 4 \times 5$.

95

In the following two short stories by Migueis this theme is of relatively major insportance: "A Ltha Invistivel," in Onde a Notie se Acaba, 1960), pp. 130, 131 \& 134; and "Posque te Calas, Amầndio? " Seanc Nowa, No. 1381-1382, Nowember-December 1960, pp. 338-340. In the followirg two uvrks this theme is of only minor importance: $A$ Ercola do Panaíso, 2nd ed. ALisbon: Estúdios

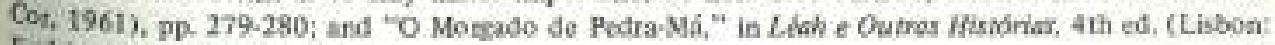
Estüdsoi Cor, 1968), p. 239.

96

Miencis published the followine works on this subject: "Palavras Imparciais: A Margem da

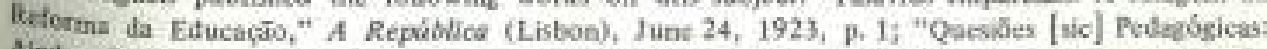

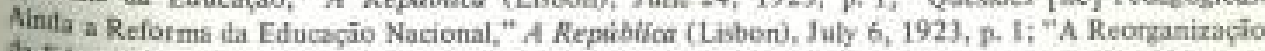

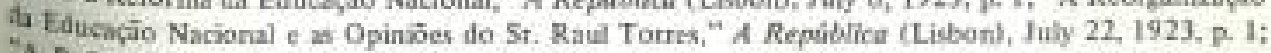
"A Ruforma da Educacto: Idealistas e Argentirios," A RepúNicz, August 2, 1923, P. 1; "Reorgeni. 


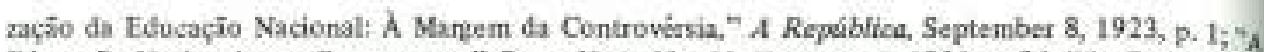
Educaçio Nacional e os Orçamentos," Señ Nows, No. 41, February 1, 1925, D. 95; "Os Catedráticor Rectamam!," Seara Nove, No. 52, Septenber 1, 1925, p. 67; "Escolas Privadas, Sanidade Escolat? Seara Nove, No, 95, hely 15, 1926, pp. 451-454: "Roflexōes de an Burgués - A Inútil Fibosofre," Sevra Now, No, 620, July 1, 1939, pp. 28-31; "Da Jinela do Meu Quarto," in Ë Proibido Apontar Repenōes de um Burgué: - I (Lisbon: Estúdios Cor, 1964), Pp. 73-96; Translation \& adaptatios of

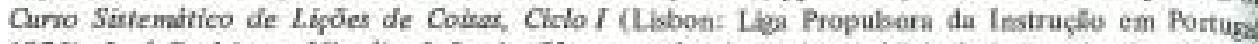
1926). José Rodrizaes Miguéis, Jodo da Cämara snd othen also published three school readets: 1 Excola e A Vida; $O$ Meu Liwinho; and $O$ Que Nde Apwendenos, all published by Livrarias Avlland Bertrund in Lisbon in 1928 .

99 In the following works by Miguéis this theme is of major importance: "Enizmal," \n Acidente," both in Onde ₹ Noite se Acaba, 3nd at. (Lisbon: Estadios Cor, 1960), Dp. 17, 21 ant

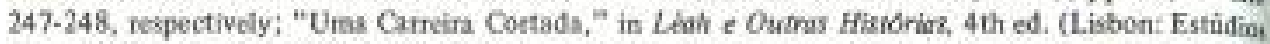
Cor, 1968), pp. 183, 193-194; A Escola do Paraiso, 2nd ed. (Lisbont Estúdios Cor, 1961) pp, 28-19 $35-41,88,117,146-147,224-226,228,233-235,252-253,261,285,295,321,340-345,349-351$ "Arrox do Ciu," in Gente da Tercotra Caxe (Lisbon: Estadios Cor, 1962), pD. 68-69; and "Sob 1 Chuva Putificadors," Linhe Genal (Leiria, Portugal), Marcti 17, 1932, D. 2. In the following works this theme is of enly minor importance: Rfícor Feliz, 3rd ed. (Lisbon: Estúdios Cor, 1965), pp. 34, 40-41: "Morte de Homem," "A Mancha nio se Apaga," "O Chapelinho Amarelo," "A Linha Invisivel" and "Heleza Orgulhosa," all five in Onde a Nodre se Acabd, 3rd ed. (Lisbon: Estudios Cor, 19602 pp 43-44; 76; 113-114; 126, 132, 163 and 267, respectively: "Saudades para a Dona Genciana," it Leah e Outrss Hiadrim, Ath ed. (Lisbon: Estiodios Cor, 1968), pp. 208 \& 215; Uma Aventuri Inquietante, 2nd ed. (Lisbon: Estúdios Cor, 1963). pp. 71, 235 \& 248; "Gente da Terceira Classe," "0 Cosme de Riba-Dauro," " "Mucha Patal'" and "A Dïsseldorf, num Pulo," all four in Gente da Terceh Clesse (Lisbon: Estidios Cor, 1962), pp. 28; 75; 154-155, 157-158; and 162, 163, 172, respectively. and "Porque te Calss, Amíndie?", Spana Nona, No, 1381-1382, November-December 1960 pD. 338-339,

92 Joot Rodtizaes Miguéts, "Reflexôes de um Burguľs - Apologla da Atrombiose," Seara Nons, No, 610, April 22, 1939, pp. 183-186 and "Crónica da Cidade: Á Margem," A Repáblica (Lisbon) Miy 19. 1923, p. 2 [Siened "R.M."]

99 In the following short stories by Mzuéis this therne does not appear, "Regreeso à Cipnla da Pena" and "A Importăncia đa Fises do Cabelo," both in Léat e Oumas Hisnarias, 4th ed. (Lisbon Estúdios Cor, 1968), pp. 115-133 and 161-179, respectively; "O 'Crime Perfeito", "No 'Sucha Plata!, "A Daisseldorf, aum Pulo" and "Primeiro. Encontro com o Transcendente," all four in Gesete of Tenceira Classe (Lisbon: Estódias Cor, 1962). pp. 129-149; 151-157; 159-175 and 189-201.

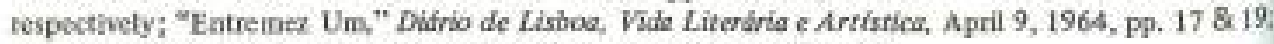
and "Lodo," O Tempo e o Modo, No. 47, February 1967, pp. 223222.

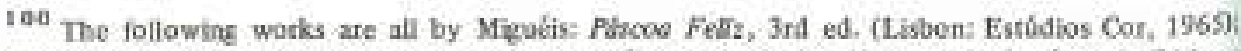
"Morte de Homem" and "A Mancha nâo se Apaga," both in Onde a Noúre se Acabe, 3rd ed. (Lisbon Estúdios Cor, 1960), Dp. 35.67; and 69.99, respectively; "Léah," "Pouca Sorte com Barbeinos," asd "Uma Carrein Cortada," all throe in Leah e Osinas Berrories, 4 th ed. (Lisbon: Estúdios Cor, 1968). pp -7-35; 91-113 and 181-195, respectively; A Escola do Furaiso, 2nd ed. (Lisbon: Estúdios Cor. 1963); "Gente da Terceira Classe," "O Vajante Clandestino," "Arroz do Cé," "O Cosme dt Riba-Dowov," and "Perdāo, Frau Schwarz!" " all five in Genie da Terceina Classe (Lisbou! Estúdios Cof, 1962). pp, 7-31; 33-47; 63-69; 71.91 and 177-187, respectively; "Milagre de Joane," Sewra Nor6, No. 26, August-September 1923, pp. 34-36; "Noite de Festa," Didnio de Lisbor, Suplemento de Nusil? December 24, 1963, pp. 1 \& 2; "Sob a Chuva Punflieadors," Linhe Geval (Leiria, Portugal). March 17, 1932, p. 2; "Os Desentendidos," Dírio de Lbbor, Vida Literirio e Artística, August 25, 1960 vo. 17 \& 18; and "Porque te Calas, Amindio?," Seare Noss, No.1381-1382, Novembvr-Decetr bet 1960, pp. 338-341. 
101 In the following wotks by Migueis thas theme is of major importance: Pdscor Feliz, 3to ad. (Lishon: Estúdios Cos, 1965); "A Mancha wōo se Apuza," in Onde a Noüte se Acabla, 3rd ed, (Lisbon: fatudios Cor, 1960), pp. 69.99; "Léah," "Pouca Sorte oom Barbeiros," and "Uma Carreira Cortado," all three in Leah e Outras Histiorias, 4th ed. (Lisbon: Estudios Cor, 1968), pp. 7-35: 91-113 and 181-195, respectively; A Escolo do Panuiso, 2nd ed. (Libbon: Estúdios Cor, 1961), pp. 25-26, 27, 46 , 62. 192, 219, 258.259, 262, 302, 316, 327: "Gente da Terceina Classe," "O Viajante Clandestino," "Arroz do Cta," and "Pendilo, Frau Schwarzl," all four is Gente da Terceina Clarse (Lisbon: Estúdios Cor, 1962), pp. 7.31; 33-47; 63.69 and 177.187, respectively; "Noite de Festa," Dibrio de Lisboe, Suplemento do Natal, December 24, 1963, pp. 1 \& 2; "Sob a Chuva Pusificadora," Linha Geral (Leirit, Portugal), March 17, 1932, D. 2; "Os Deseatendidos," Didrio de Lisbod, Vida Literirie e Antistica, Auguast 25, 1960, pp. 17 \& 18; "Porque te Calas, Amandio? ", Seura Nora, No, 1381-1382, Norember-Dectmber 1960, pp. 338-341. In the following works this theme is of only minot ingortance: "O Chapelinho Amirelo," "Cinzas de Inč̉ndio," and "O Acidente," all three in Onde a Noire se Acabs, 3nd ed. (Lisben: Estúlios Cor, 1960) pp, 106-107, 112; 175-176; and 240-241, etspectively: "O Natal do Dr. Crosby" and "Ssudades para a Dons Genciane," both in Léahe e Oumar fistórias, 4th ed. (Lisbon: Estúdios Cor, 1968), pp. 63-69, 85-86 and 215, respectively; Umat A renture Iaruietante, 2nd ed. (Lisbon: Estidios Cor, 1963), pp. 35, 37, 104-105; 116, 129 \& \$36; "Natal Branco," "A Esquina-do-Vento," "O Anel de Contrabando," and "Silvestre, os Seus Amores," all fout it Gente da Terceine Classe (Lisbon: Estúdios Cor, 1962), pp. 61; 108; 115 and 206.

102 In the following works by Migueis this theme is of major importance "Morte de Homem," in Onde a Noite se Acona, 3ed ed. (Libon: Estúdios Cor, 1960). pd. 35-67; "O Cosme de Riba-Douro," in Ledah e Ourras Historias, 4th ed. (Listoni Estídios Cot, 1968), pp. 75-78; and "Miliugre de Joane," Sere None, No. 26, August-September 1923, pp. 34-36. In the following works this theme is of only minor importance: "Uma Viagem na Nossa Tern," and "O Morgado de Podra-Má," both in Léah e Outras Hisnórias, 4th ed. (Lisbon: Estúdios Cor, 1968), pp. 64 \& 238; "A Esquina-do-Vento," and " "Ite, Missa Est'," beth in Gente de Terceire Clesse (Lisbon: Estudios Cor, 1962), pp. 108; and 248, 250, 252, respectively; "Como Êles se Amanaml... (Conto Veridico de Amor e de Guerra)," (D. Ditrib de Noticies, (New Bedford, Mass) Novembet 22, 1940, p. 2 [Signed "Leonardo Moreira"]; "A Sombra," Seara Nosa, No. 112, December 22, 1927, pp. 313-314.

103 In the following works by Migués this theme is of major importance: Pfacos Feliz, 3nd ed (Lishon: Estídios Cor, 1965), pp, 31 \& 41; "O Acidente," in Onde a Noite se Acuba, 3nd ed. (Lisbon: Eutúdios Cor, 1960), pp. 235-259; A Escola do Furatso, 2nd ed. (Lisbon: Estúdios Cor, 1961), pp. 9. $10,28,47,60-61,64,81$ \& 148; and "Artoz do Céu," in Gente de Terceina Clesse (Lisbon: Estúdion $\mathrm{Cot}, 1962)$, pp. 65-69, In the following stories this theme is of only miner importance: "Morte de Honsem," in Onde o Noite re Acebo, 3rd ed. (Lishon: Estídios Cor, 1960), p. 39; and "Natal Branco," in Gente da Terceine Classe (Lisbon: Estúdios Cot, 1962), pp, 54, 55-56 \& 58.

104

In the following woiks by Mizuéis these problems afe all of minor importanoe: Piscoed Feltis, 3rd ed. (Libbon: Estúdios Cor, 1965). pg, 41-42, 59-60; "Gente da Terceira Classe," in Gente da Tencerne Classe (Lisbon: Estúlios Cor, 1962), pp. 26-27; and Umi Aventura Inquietente, 2nd od. (Lisbon: Eutúdios Cor, 1963). pp. 106-107.

$\operatorname{tos}$

In the following works by Miguéis this theme is of major importance: "Morte de Homem," and "A Linha Invisivel," both in Onde a Noite se Aceba, 3rul ed. (Lisbon: Estúdios Cor, 1960), pp. 35-67 and 140-171; and "Uma Curreirn Cortada," in Lán e Outras Hirtórias, 4th ed. (Lisbon: Estudios Cor, 1968), A. 191 . In the following works it is of only minor importance: Piscos Feliz, 3rd ed. (Linbon: Estódios Cor, 1965), po. 38. 75-76, 81, 85-86; "Eniemal," "O Acidente" and "Beleza Orgulhosa," in Onde a Noite se Acaba, 3nd ed. (Lisbon: Estudios Cor, 1960), pp. 33; 239.260; 265-266, respectively; "Liah," "Dezasseis Horas em Misslio Secreta," and "O Morgado de Pedra-Má," all three in Lieh e Outres Historias, 4th ed. (Lisbon: Estidios Cot, 1968), pp. 31; 141-142; and 265; respectively. 
106 In the following works by Miquóis this theme is of major inaportance: "A Linha Invisível, ha Onde a Noite se Acabs, 3rd ed. (Lisboni Estúdios Cor, 1960), pp. 119.171; "Uma Viagem na Now Terra." in Leat e Outras Hisrdriar, 4th ed. (Lisbon: Estudios Cor, 1968) pp. 37-63. In the followion works this theme is of only minor importance: "O Acideate," in Onde a Noite an Acubs, 3nd od, (Lisbon: Estúdios Cor, 1960), pp, 237.238; "Saudades para a Dona Genciana," in Lfoh e Ourraj

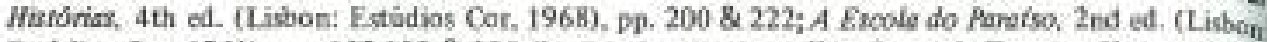
Estúdios Cor, 1961), pp. 102-103 \& 335; "A Esguira-do-Vento," in Gente da Terceiva Classe (Lisboin. Estádios Cor, 1962), 93-111; "Entremez Um," Didrio de Lisbod, Vida Liferáric e Arrística, April 9. 1964, pp $17 \& 19$.

107 In the following works by Migueis this subject is of major importance: "Cinzas de Incindio," in Onde a Noire se Acroba, 3rd ed, (Lisbon: Estridios Cor, 1960), pp. 173-233; "A Importíncin da Risca do Cabelo," and "O Motgado de Pedra-Má," both in Léah e Ou Dres Historiaz, 4tb ed. (Lisbon: Estadion Cor, 1968), pp. 161-179 and 229-269, respoctively; A Escola do Rarriso, 2nd ed. (Lisboa: Estúdios Cor, 1961), pp. 39-40, 72-74, 174-176, 287-289, 290-295, 299 \& 301; and Hrirteiro Encontro com 0 Trasscendente," in Gente da Tencein Clese (Lisbon: Estudios Cor, 1962), p. 192. In the followity works this theme is of only minor importance: Pdscod Feit, 3rd at. (Lisbon: Estódios Cor, 1965). pp. 33 \& 38, "Morte de Homem," "O Acidente," and "Beleza Orguithosa," all three in Onde a Noite ae Acrbe, 3sd ed, (Lisbon: Estúlios Cor, 1960), pp 46; 224; and 261-271, respectively.

108 Migueis jublished the following articles an this subject: "Poeira da Rua: Flores," A Republita (Lisbon), June 6, 1923, p. 1; "Poein da Rua: O Préso," A Repíblica, June 27, 1923, Pp. 1 \& 2 "Reandos de um Burguếs (D)," Seera Nove, No, 112, Decimber 22, 1927, pp. $307-308$ and "TablWides: Bovery, 1964," Seant Nove, No. 1447, Mtsy 1966, pp. 136-138.

I09 In the the followirg works by Miguéis this theme is of minor importance: Pfiscod Feliz, 3rd ed (Lisbon: Estíbios Cor, 1965), p. 49; "Morte de Howem," in Onde a Naite se Acaha, 3rd ed. (LisbonEstúdios Cot, 1960), p. 42; "A Importáncia da Rises do Cabelo," in Lérh e Outras Nistórias, 4 th ed. (Lisben: Estúdios Cor, 1968), p. 178; Ums Aventim Inpuletante, 2nd ed. (Lisbon: Estílios Cat, 1961), pp. 320-321; "Muchs Platal"," "A Dasseldorf, num Pulo," and "Primeiro Encontro com o Transcendente," all three in Gente do Tereeira Carze, (Lisbon: Estúdios Cos, 1962), DD. 155; 166; and 200 , respoctively.

110 In the following three short stories by Mikuéis this theme is of major importance: "Gente da Terceira Classe," "O Viajeste Clandestino," "O Cosme de Riba-Dosuro," all three in Gente da Terceine Classe (Lisbon: Estadios Cor, 1962), pp. 7-31; 33-47; and 79, 80, 86-87. In the following works this theme is of only mitor importance: "Beleza Orgalhosa" in Onde a Noite se Acaba, 3rd ed. (Lison: Estícdios Cos, 1960), pp 268-269; A Eroola do Porafio, 2nd ed. (Lisbon: Estídios Cor, 1961). pp. 84-85; "O Natal do Dr. Crosby," in Lésh e Outras Histórias, 4tbed, (Lisbon: Estidios Cor, 1968). pp. 74, 76, 78-79; and "Natal Branco," and "Arrot do Cét," both in Gente de Tereelra Classe (Lisbon: Estúdios Cor, 19627 , pp, 55 and 66, tespectively.

111 In the following two short stories by Mesecis this theme is of major importance: "Befezl Ongulhosa," in Onde a Noite se Acabs, 3rt ed, (Lisbont Estádios Cor, 1960), pp. 261-271; and "0 Cosme de Ribs-Douro," in Gente de Tenceine Casse (Lisbon: Fistúdios Cor, 1962), pp. 71 -91.

112 In all the followirg nire works by Miguéis this theme is of onily minor importance: Pdscou Foliz, 3rd ed. (Lisbon: Extudios Cor, 1965), pp. 75-76, 81, 85-86; "Derzssseis Horas em Missto Secreta," and "Sundades pana a Dona Genciana," both in Léah e Outrax Hirtorias, 4th ed. (Lisbon: Estudios Cot, 1968), pp. 146 and 202, 206-207, 228, respectively; Uma Aventund Inquiefante, 2nd ed. (Lisbon: Estúdios Cor, 1963), pp. 95.99, 105 \& 254;A Escola do Purafso, 2nd ed, (Lisbon: Estúdios Cor, 1961). pp. 23, 276-284, 313, $346 \mathrm{\&} 367$; "Cente da Terceira Classe," "O "Crime Perfeito'," and "A Esquina-do-Vento," all throe in Gente da Terceine Carse (Lisbon: Estudios Cor, 1962), pp. 15, 16, 21 , 23; 132; and 105, 107, ruspectively; "Sob a Chava Purificadora," Linha Geral (Leiria, Portugs?l. March 17, 1932, p. 2. 
113 In the following two works by Miguéis this theme is of major importance: "A Mancha nilo *e Apte." in Onde a Noite se Acabe, Jrd ed. (Lisbon: Estudins Cor, 1960), pp. 72-74; Uma Arenfura fogeretante, 2nd ad. (Lisbon: Estation Cor, 1963), pp. 202, 211-212. In the following two works it is ef anty minos importance: "Pouca Sarte cam Basbeiros," in Lésh e Outras Histórias, 4th ad. (L.isbon: 1.9tudios Cor, 1968), D. 106; and A Ereola do Arralso, 2nd od. (Lisbon: Estudios Cor, 1961), p. 255,

114 In all the following works by Miguéis this theme is of only minor importance: "Léah," and "Saudades para a Dora Genciana," in Léah e Outras Bistórias, 4th ed. (Lisben: Estídios Cor, 1968). sp. $9-10,13,17,19,22,26-28,34-35$; and $208,209,211,212-213$, respectively: Ume Aventure Foquictante, 2nd ed. (Lisbon: Estudios Cor, 1963), pp. 29, 229; A Escolo do Aarafbo, 2nd ed. (Lishon: Estiatios Cor, 1961), pp. 281-282, 287-289, 293, 295, 299, 301, 312 \& 343.

${ }^{115}$ In the following short story by Meutis this theme is of major importance: "A Importincia da Rises do Cabela," in Lèn e Outras Historias, 4th tu. (Lidbon: Fistúdios Cor, 1968), DD. 175-176 \& 179-180, In the following works it is of only minor importance: Pascas Fellz, 3rd ed. (Lishons Estúdips Cor, 1965), p. 42; "Uma Viagem na Nosia Term,". in Liah e Oubas Hisnoriss, 4th wi. (Listoa: Estídios Cor, 1968), p. 64; "O Anel de Contrabando," and " "Mucha PlataI"," both in Gerte de Tenceiru Classe (Lisłon: Estúdios Cor, 1962), pp. 124, and 151, 158, respectively.

116 In the following works by Mzyucis this theme is of only minor importanes: Paizcoe Feliz, 3ed ed. (Libon: Estudios Cor, 1965), pp. 92.94, 95 \& 156; "Saudades para a Dona Geaciania" and "O

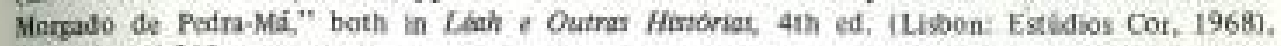
TV. 212 ; and 253 , respectively.

${ }^{117}$ In this work by Msuéis this theme is of major importance; Uma Aventura Impreietanfe, 2 nd od. (Liston: Estúdios Cor, 1963), pp. 101, 141-142. 145-153, 193-197, 249. In the following work this theme is of only minor importance: Fatcas Fellt, 3rd of. (Lisbont Estúdios Cor, 1965), pp. 11-18.

II" In the following works by Meatis this theme is of major importance: Umi Aventura Maquietante, 2nd ed. (Lisbon: Estódios Cor, 1963), pp. 32-33, 42, 46, 89, 103-111, 144, 254, 261 \& 264; A Escolo do Funalso, 2nd ed. (Lisbon: Estúdios Cor, 1961), pa. 63-64, 92, 272-274 \& 296 "Ferdio, Frasu Schwarzl," and "A Dasseldorf, num Polo," both in Geuse da Tercerna Clssse (Lisbon: Estídios Cor, 1962), pp. 178, 180, 182, 184 \& 186; and 167, respectively; "A Sambrin," Seara Nona, No. 112, December 22, 1927, pp. 313-314. In the following works this therne is of only minor importance: Piscou Feliz, 3rd ed. (Lisbon: Estídios Cor, 1965), j. 49; "Cinzas de Incéndio," in Onde a Noite se Acshe, 3rd ed. (Lisbon: Estudios Cor, 1960), p, 176; "Pouca Sorte com Barbeiros," and 'Saudades para a Dona Gencians,' both in Liah e Outrat Hostbrias, 4th ad. (Lisbon: Estudias Cor, 1968), vp. 101 and 206, 21 8-220, respectively; "Gente da Terceira Classe," "O Viajante Clandestino," "Natal Branco," "O Cosme de Riba-Douro," asd "O Anel de Contrabando," all five in Gente do Terceine Classe (Lisoon: Estúdios Cor, 1962), pp; 17 82 26; 36; 53; 79; and 115, respectively; and "Entremez Um," Didirio de Lisbos, Vode Lisendria e Artistice, April 9, 1964, pp. 17 \& 19.

${ }^{119}$ In the followirg five works by Miguéis this problem is of major importance! "Regresso à Cúpula de Pena," in Léah e Outras Histórias, 4th od. (Lisbosi Estadios Cor, 1968), pp. 115-133; U/ms

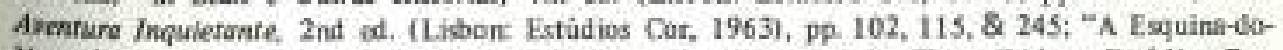
Veato," and "Silvestre, os Seus Amores," both in Gente de Terceira Clesse RLisbon: Estudios Cor, 1962), pp. 93-111 and 203-221, rtspectively; and "Lodo," o Tempo e o Modo. No. 47. February 1967 pp- 223-229.

120

In the following two short stories by Mizuéis thrs thene is of minor impartance: "Saudades fara a Dona Genciana," in Libh e Outras Lfistóries, 4th od. (Lisboni Estudios Cor, 1968), pp 206, $209,212-214,216$ \&: 226; and "Ponque te Calas, Amandio?" Seara Nove. No. 1381-1382. Navember-December, 1960 , pp. 338, \& 339 .

121

In the folfowing works by Micuóis this theme is of only minor importance: Aiscod Feliz, Jrd ed. (Lisbon: Estudios Cor, 1965), p. 43: "Dezasseis Horas em Misslio Secreta," in Lèah c Ovatras Histórass, 49 ad. (Lisbon: Estúdios Cor, 1968), p. 155; asd Uma Aventura Inquierante, 2od ed. (Liston: Estuidias Cor, 1963), pp. 30, 113, 115, 201 \& 260 
122 In the following works by Migueis this theme is of major importaece: "Léah," and "Derassẹn Horas em Missio Secreta," both in Láah e Outrus Histórias, 4th ed. (Lisbon: Estuidjos Cor, 1964) pp. 10-13 \& 21; and 139-141, respectively. In the followtng works this theme is of only minse importance: "Cinzas de Incèndie," in Onde a Noite se Acabs, 3rd ed, (Lisbon: Estúdios Cor, 196ti). pp. 176-177, 183-185; "O Natal do Dr. Crosby," "Pouca Sorte com Barbeiros," and "A Importinzia da Risca do Cabelo," botk in Làh e Outras Históriex, 4th ed. (Lubon: Estídios Cor, 1968), pp. 78. 106 and 175, respectively: "Ciente da Terceira Classe," "O Viajaste Clandestino," "Arroz do Cles,"

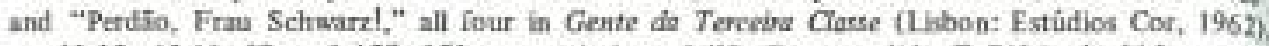
Pp. 11-13; 45-46; 67; and 179, 181, respectively and "Os Desentendidos," Didrio de Lisbor, Vids Liteniria 6 Artistica, August 25, 1960, p, 17.

123 In the following works by Miguéts this theme is of major impostance: "Regresso à Cópula da Pena," "Saudades pasa a Dora Genciana," both in Lèth e Oubres Historiat, 4th ed. (Libon: Estúdias Cot, 1968), pp. 115-133; and 197-227, tespectively; and "Lodo," O Tempo e o Modo, No, 47. February 1967, pp. 223-229. In the following two short stories it is of only minor importance: "Uma Viagem na Noss Terra," and "Pouca Sorte con Barbeiros," both in Leah e Outres lifistoriar, 4th ed (Lisbon: Estídios Cor, 1968), pp. 45, 49, 50, 53 and 112-113, respectively.

124 Josk Rodriques Meuetis, "Relatório do Bolseiro Jose Rodrigues Miguess: Ensino de Criançat Anotmais, Retardadas ou Insuficientes, ma Bélgica," in Relanorlos das Vagens de Estudo dos Bolveinos: Aurea Judile Amaral, Juime Miximino Gouveia Xarier de Brifo, Jowo de Sousia Canatho, Irene de Cáu

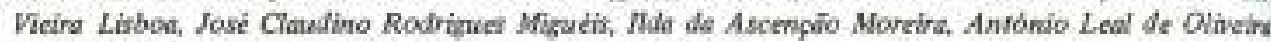
(Lisbon: Juata da Educação Nacional, 1933), pp. 187-227.

125 José Rodriz̧ues Miquéis, Um Homem Sarri à Morte - Com Meì Cara, 2nd ed. (Lisbon: Fstúlios Cor, 1965).

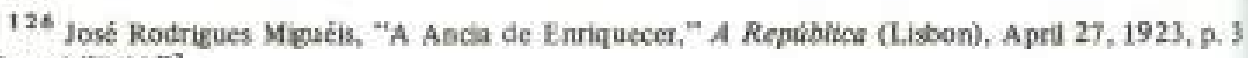
[Siened "R.M"]

127 In the following works by Megueis this theme is of major importance: "Os Desenterdidos," Dibino de Lisbon, Vida Literíle e Artisrice, August 25, 1960, pD. 17 \& 18; and "O Anel de Contrabando," in Gente da Tacein Clesse (Lisbon: Estadios Cor, 1962), pp 123-124, In the following works it b of ondy minor importance: "O Morgado de Podra-Ma," in Letwh e Outras Hirsdriar. 4th ed. (Liston: Estúdios Cor, 1968), sp. 250, \& 266; A Eroole do Arratso, 2nd ad. (Lisbon: Estúdion Cor, 1961), pp. 85, 93, 95 \& 254; "Gente da Tetceina Classe" in Gente de Terceinu Claste (Lispos: Estúdios Cor, 1962), p. 23.

128 In the following short story by Migués this theme is of major importance: "Enigral, "in Onile $e$ Nolre se Acaba, Jed ed. (Iisbon: Estudios Cor, 1965), p. 15. In the followire work it is of only minor importance: Uma Anentira Inquietante, 2nd ed. (Lisbon: Estiadios Cos, 1963), Pp. 111.112.

129 Josḱ Rodrigues Migaćis, "Cadeia da Bos-Sorte," A Noticáa (Lisłon), Mlay 23, 1928, p. 4.

130 In the following short stary by Migutis this theme is of major importance: "Entemal," in Onde a Noite se Acmba, 3rd ed. (Liston: Estibdjos Cor, 1960), p. 25. In the following works this theme is of only minor importance: Psscoe Feliz. 3nd ed. (Lisbon: Estuitios Cor, 1965), pp. 145-147; "O Norzado de Pedra-Mi," in Leah e Outras Historias, 4th ed. (Libonz Estudtios Cor, 1968), pp. 232, 240-241; A Eacola do Panarso, 2nd ed. (Lisbon: Estúdios Cor, 1961), pp. 16, 65, 177.178, 179.182; "A Esquina-lo-Vento," in Gente da Tencetin Classe (Lisbon: Fstuidios Cor, 1962), p, 108.

131 Mieulis published the following articles on this subject: "Crótica ta Cilade: A Margen," A Repubilice (Lisbon), May 16, 1923, p. 2; "Pocirn da Rua: Miss Dolotosa," A Repáblica, June 17, 1923. p. 1; "Poeira da Rua: Meia Noite," A Repiáblica, July 20, 1923, p, 1; "Reflexס̃es de um Burguís: Crianças," O Gboho (Lisbon), November 11, I933, p. 4: "Reflexỏes de um Burguếs - Os de Cima e as de Baixo," Seara Now, No, 612, May 6, 1939, pp 223-226. 
132 In the following work by Mzucis this thense is of major importance: "Saudades para a Dona Gendana," in Lfah e Outras Hirtónios, 4th ed, (Libon: Estudios Cor, 1968), pp. 209, 210, 211, 212, $314,200,8$ 226. Is the followite works it is of orly minor impartance: A Escole do Parafso, 2 nd ed. iLsbar: Estúdies Ces, 1961), pp. 27-28, "O Acidente," in Onde a Noite se Acuĺs, Ird ed. (Lisbon: Erudios Cot, 1960), p. 244; Pátroe Fefit, 3rd ed. (Lisbon: Estúdios Cot, 1965), p. 27.

$1{ }^{33}$ In the following work by Miguéis this theme is of major importanes: Uma Awwrusu

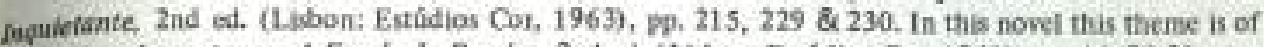
enly minor importance: A Escola do Parriso, 2ad ed. (Lisben: Estúdios Cot, 1961), pp, 44, $90-91$.

i 94 In the following short story by Mizueis this theme is of major importance: "O Mongade de Pedra-Má," in Linh e Outras Harórias, 4th ed. (Lisbon: Estidios Cor, 1963), p. 261. In the followins hort story it is of only minar importance: "O 'Crime Perfeito'," in Gente de Tenceina Clarse (Liston: Estidios $(0 t, 1962)$, DD. $131,138 \& 141$.

I3S José Rodrigues Miguéis, "Relatúrio do Bolaciro José Radrigues Migutis: Ensirio de Crianças Anormais, Retardadas ou Inaticientes, na Bélgica," in Relatdrios das Viagens de Estudo dos Bolsevert (Lisban; Junta da Educaçio Nacional, 1933), Fp. 187-227.

136 In the following works by Migukis this problem is of minor importance: "Léah," is Läat e Ournas Historiar, 4th ed. (Lisbon: Estudios Cor, 1968), pp. 17-18; "Gente da Terceira Classe," in Gente da Terceirs Classe (Lisbon: Estúdios Cot, 1962), p. 19; and "Porque te Calas, Amándio? ." Sears Nove, No, 1381-1382, November-December 1960, pp. 338-339.

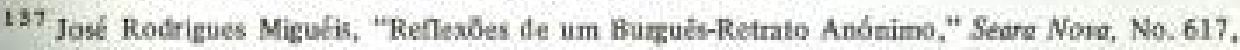
June 10, 1939, pp. 323-325.

136 José Rodrigues Miguéis, "O 'Crime Perfesito"," in Gente dz Terceira Classe (Lisbon: Estádios Cor, 1962), pp. 132-133.

139 José Rodrigues Migoeis, "O Exito que Mata," Seare Nove, No. 1321-1322, June 1956, pp. 83-84, This article asas signed "Pedro SahiL""

${ }^{140}$ In the following work by Migueis this theme is of major importance: Uima Aventum lnquielante, 2nd ed, (Lisbon: Estídios Cor, 1963), pD. 227-230. In the following two works it is of only minor importanee: "O Morgado de Pedra-Ma," in Lelah e Outras Hissorias, 4th ed. (Lisbon: Extúdias Cor, 1968), pa. 257-260; and A Escole do Parsisa, 2nd ed. (Lisbon: Estúdios Cor, 1961). f. 23.

${ }^{141}$ In the four following works this problem is of major importance. The works are (by Mẹuéis): "Sitvestre, os sems Amores," in Gente de Tenceira Clatse (Libon: Estúdios Cor, 1962), pp. 203-221; "A Mancha nio se Apagz," and "A Linha Invisiveb," in Onde a Notie se Acshe, 3rit ed. (Lisbon: Estúdios Cor, 1960), pp. 95.98 and 135, respectively; and "Uma Carreira Cortada," in Láah e Outres Historint, 4th ed. (Lisbon: Estudios Cor, 1968), pp, 188-195.

192 In the following two short stories by Miguéis this theare is of only minor Importance: "A Linlra Ievisivel," in Onde a Noire se Acabat, 3nd od. (Lisbon: Esthilios Cor, 1960), p. 136; and "Pouca Sorte

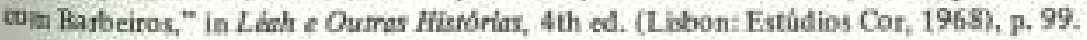

143

In the following work by Migueis this theme is of major importance: Una Anewtura Inquietante, 2nd ed, (Lisbon: Estidios Cor, 1963). po, 32, 133 \& 251. In the followine shert stories it is af only minor importance: "O Natal do De. Crosby," in Lejah e Outras Finnorias, 4th ed. (Lisbon: Evúdios Cor, 1968), p. 25; and "Gente da Terceira Classe," in Gente da Terceira Claste (Lisbon: Estintios Cor, 1962), pp. 20-21.

144

In this short story by Migubis this theme is of major importance: "O 'Crime Perfeito'," in Gente da Tertebra Casse (Libon: Estúdios Cor, 1962), pp, 131-132. In the next short story it is of only miner importance: "Gente da Terceira Classe," in Gente da Tereeins Clesse (Lisbon: Estuidios Cor, 1962), Pp, $29-30$. 
145 Jocé Rodrigues Migués, "A Manctaz năo se Apaga," in Onde a Noite se' Acabu, 3rd ed. (Lisbege Estútios Cor, 1960), pp, 69:99.

140 Jas Radrigues Migaěis, "A Fsquina-do-Vento," in Gente da Terceina Clasere (Lishon: Estüdian Cor, 1962), pp, 95-111.

${ }^{147}$ In the following works by Miquóis these problems are of minor importancoi $A$ Escole do Parafo, 2nd ed. (Lisbon: Estúdios Cor, 1961), pp. 117.118; Cmat Arenfera Inquirrante, Znd of (Liфon: Estádios Cot, 1963), pp. 29 \& 34; and "Yocha Platat", in Gente ale Terceira Casse (Lisbon! Estúdios Cor, 1962), pp. 153-154.

${ }^{148}$ Miguéis pablished the following on this sabject: "O Fato Coçado," in Et Praibido Aponzar Reflexder de um Exugues - I (Lisbon: Estádios Cor, 1964) PD. 19-26. This theme is of only minor importance in the following short story: "O Cosme de Ribu-Douro," in Gesite da Terceina Cutse (Lisbon: Estúdios Cor, 1962), p. 81.

${ }^{149}$ Miguéis published "Como Eles se Amavam! .... (Conto Verfitice de Amor e de Guerra)" in five installments in Distro de Notlcise (New Bedfond, Nass). This problom is of mpjor importanoe in this short sory, particularly in: P. II, Novernber 23, 1940, p. 2: and Pt. III, November 25, 1940, D. 2 All the installments were signed "Leonardo Moreira."

150 This theme is of minor importance in Miguéis" "Milagre de Joane," Seara Nove, No. 26, August-September 1923, p. 35; and "Saudedes para a Dora Gencinna," is Lësk e Outres Hirtóniar, 4th ed. (Lubon: Estútios Cor, 1968), pD, 205 \& 210.

151 In the following wotk by Mizuéis this theme is of major importance: "Leah," in Léh e Qumat Efistarias, 4th ed. (Lisbon: Estidios Cor, 1968), pp. $15 \& 31$. In the following short story it is of only minor importance: "Porque te Calas, Amindio?" Seara Nowe, No. 1381-1382, November-Dedember 1960, v0. $338-339$.

152 José Rodriques Miquếis, "O 'Crime Perfeito"," in Gente da Tereeira Classe (Lisbant Estúdige Cor, 1962), p. 142

${ }^{153}$ In the following work by Migueis this theme is of major importance: "A Esquina-do-Vento," in Gente de Terceina Clesse (Lisbon: Estudios Cor, 1962), p. 109. In the following works it is af minar importance: Psscoa Fellz, 3rd ed. (Lisbon: Estudias Cor, 1965), pp. 31.32: "A Mnncha não se A pagz," and "Morte de Homem," both in Onde a Noite se Acabe, 3rd ed. (Lisbon: Fstídios Cor, 1960), Pp. 82 and 46, respectively.

154 This theme is of minor importance in Miguéis" "Saudades para a Dona Genciana," in Léah $e$ Otras Hisıóriss, 4th ed. (Lisbon: Estúdios Cor, 1968), p. 207.

I55 This theme is of minor importance in Migueis' A Escola do Frafiso, 2nd ed, (Lisbon: Estidios Cor, 1961), pe 98-101.

I56 In the following work by Migutis this theme is of malor importance: "A Esquina-do-Vento," in Geme do Tercedra Carse (Libon: Estidios Cor, 1962), p. 109, In the followine work it is of anly minor importance: "Silvestre, as Seus Amores," in Gente da Terceira Classe (Lisbon: Estádios Cor, 1962), pp. $211-212$.

157 In the following works by Miguéis this theme is of ovly minar importascast "O "Criete Perfeito?", if Gente da Terceira Classe (Lisbon: Estủdios Cor, 1962), pp. 136 \& 146;" "Saudades pars a Doma Genciana," in L, dah e Oatrar Historiak, 4th ed, (Lisbon: Estudios Cor, 1968), p, 222; and Ums Arenrura Inqudefante, 2nd ed, (Lishon: Estúdios Cor, 1963), pp. 22, 23-24, 25, 33, 41-43.

I 5 " In this short story by Mirueis thas theme is of minor importance: "Enigmal," in Onde a Noike If Acabo, 3rd ed. (Lisbon: Estídios Cor, 1960), pp. 19-23, 24 \& 28.

159 In this shont story by Mliguéts this theme is of minor imporlance: "O 'Crime Perfeito'," in Gewe du Tercuire Classe (Liston: Estúdios Cor, 1962), pp. 135 \& 146. 
160 Josế Rodrigues Migućis, A Escolo do Aurstso, 2nd ed, (Lisbon: Estúdios Cor, 1961), p. 137.

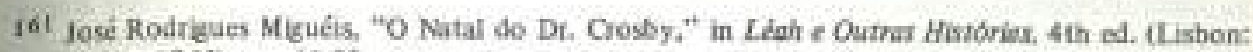
Estidios Cor, 1968), pR. 65-89.

162 José Rodrigues Miguẹis, "Léah," in Läh e Outras Hiatories, 4th ed, (Lisbon: Estúdios Cor, 19681, pp. $18-19$

153 Josf Rodrigues Miguçis, "O 'Crimo Perfeito'," in Gente da Terceina Classe (Lisbon: Estúdios Car, 1962), p. 136 .

164 In the following two short stories by Migutis this thenxe is of major importance: "Beleza Orguthosa," in Onde a Noite se Acabs, 37d ed. (Lisbon: Estúdjos Cor, 1960), Pp. 261-271; and "Silvestre, os Seus Amores," in Genfe da Fencetro Closse (Lisbon: Fistúdios Cor, 1962), pp. 214.220.

165 In the followiry short story by Miguéis this theme is of minor importabes "O Acidente," in Onde a Notte se Acabd, 3nd el, (L.isbon: Estudios Cor, 1960), p, 238.

156 In the following work by MEquéis this theme is of minor importancer. A Fscola do funotsa, 2nd al. (Lisbon: Estudios Cot, 1961), pp. 17-18.

167 In the following short stories by Miguéis this theme is of major impostance: "A Importaiseia de Risca do Cabelo," and "O Natal do Dr. Crosby," both is Léch e Outros Historias, 4th ed. (Lisbon: Eututios Car, 1968), pa 167 and 84, respectively; and "Cinzas đe Incêndio," in Onde a Noile se Acobs, 3nd od. (Lisbon: Estídios Cor, 1960), Pp. 195-233, In the following works this theme is of only minot importance: "Morte de Homem," and "A Linha Isvisivel," both in Onde a Noite se Acaba, 3rd ed. (Lisbon: Estúdios Cor, 1960), pp. 46; and 133, 156, respectively; Uma Aventura Inquietante, 2nd ed. (Lisoon: Estídios Cor, 1963), pp. 35, 216 8. 230; "Gente da Terpeira Classe," and " "lie, Misea Est'," both in Gente da Terceinu Closie (Libon: Estudios. Cor, 1962), Pp. 29 and 247.250,

168 In the following works by Miguèis this theme is of major importance: "Gente da Terceira Cunse" nud "O "Crime Perfoito"," in Cente de Tenceina Classe (Lisbont Estúdios Cor, 1962), pp. 9-11, 17. 19 and 134, respectively; und "Porque te Cales, Amaindio? "t Seura Nova, No. 1381-1382, Noveinlyer-December 1960, pp. 338-339.

167

In the following work by Miguéis this problem is of major importance: "A Inportincia de Risca So Cabela," in Lah e Outrar Fistórias, 4th ed. (Lisbon: Estudios Cor, 1968), pp. 171-175. In the folowirg works it is of only minor importance: "Dna Viagem na Nossa Tema," in Léah e Owbar Hiunbiles, 4th od. (Lisboa: Estúdion Cor, 1968), pp 54-55, \& 59.60; Uma Aventum Inquietante, 2nd cd. (Lisbon: Estádios Cor, 1963), po, 54-55, \& 59-60; Uma A vertura Inquiefante, 2nd ed, (Lisbon: Estúdios Cor, 1963), pp. 25, 33, 41-43, 191 \& 199; A Excolo do Furatro, 2nd ed. (Lisbon: Estídios Cor, 1961), pp. 30, 114-116, 152-153, 177, 183, 192-195, 197-198, 203-205; "Gente đa Terceirn Casso," "Natal Branco," and " 'Ite, Missa Est?," all three is Gente de Terceina Carre (Lisbon: Estúdios Cor, 1962), pp. 17; 57, and 245-247, respectively.

170 Miguebs dealt with this theme in the two following novels; Umo Aventura Inquietante, 2nd ed. (Lisbonz Estúdios Cot, 1963), p. 160, and A Evcola do Paraíso, Znd od. (Lisłoon: Estádios Cor, 1961), Pp. 43, 56-57 \&368. He also dealt with this theme in his non-fictional wurk, Um Homem Sorrid Morte Com Meis Cane, 2nd ed, (Lisbon: Estudios Cor, 1965).

171

In the follawing works by Miguess this the is of major importanke. "Uma Viagem na Nosse Term," and "A Importincia da Risca do Cabelo," both in Litak e Outras Historiar, Ath ed. OLisbon: Estútios Cor, 1968), PP. 63; and 174, respectively; Uma Avennurs Inquietomie, 2nd ed. (Lisbon: Eitúlios Cor, 1963), pp. 19-30, 66, 71, 121, 139, 194, 198 \& 220; A Escole do Paralso, 2nd ed. (Lisbon: Estúdios Cos, 1961), pp. 135, 228, 234 \& 249; and " 'Mucha Platal," in Gente da Terceira Clenge (Lisbon: Estúdios Cor, 1962), p, 154. 
172 In the following works by Mgaéis this theme is of majot importasce: "O Chapelinho Amarela, in Onde a Noire se Aceha, 3rd ed. (Lisbon: Fstálios Cor, 1960), pp. 101-117; Ume Aventape Inqulerante, 2nd ed. (Lisbon: Estúdios Cor, 1963), p. 201; and "Perd50. Frau Schasarz," in Gente d4 Tereeins Carse (Lisbon: Est6dios Cot, 1962), pp. 187-188. In the following works it is onty a mino. theme: "Belcat Orguliosa," in Onde a Noite Se Acabe, 3rd ed. (Liskon: Istudios Cor, 1960), D. 268 "O Natal do De. Crosby," in Leieh e Outnas Histolries, 4th ed. (Lisbon: Estudios Cor, 1968), p. 8): "Gente da Terceirn Chasse," and "A Deisseldoef, aum Palo," both in Gente de Terceire Close (Lishon Estúdios Cor, 1962), Pp. 15 and 175 , respectively.

173 In the followirg works by Migucis this therne is of minor importanos: "Eniqmal," in Onde. Moife se Acabu, 3nd ed. (Libbon: Estúdios Cor, 1960), p. 13; "Conte da Terocira Classe," in Gemte de Terceint Classe (Lisbon: Estúdios Cor, 1962), p. 18; A Escola do Panriso, 2nd ed. (Lisbont Estúlos Cor, 1961), pp. 217, 21 8; and "O "Grime Perfeito"," in Gente die Tereetra Clesse (Lisbon: Estúdios Cor 1962), 9,135 .

179 In the followirg works by Migutis this theme is of only minor importance: "Enigma!," ant "Beleza Orgulhosa," both in Onde a Noile ze Acaba, 3rd ed. (I.isban: Estudios Cor, 1960), pp. 19 ane 270; "O Natal do Dr. Crosby," and "Pouca Sorte com larbeiros," both in Lèh e Outras flistorim, 4th ed. (Lisbon: Estúdios Cor, 1968), pp. 81 and 106, 109,110, respectively; "O Cosme de Riba-Dourp," and " "Mucha Platal'," both in Gente da Terceira Cletse (Lisbon: Estúdios Cor, 1962), pp. 89 and IS5. respectively.

${ }^{75}$ In the following works by Miguéis this theme is of only minor importance: "Deleza Otgulhnsu," in Onde a Noite se Acaba, 3rd ed. (Lisbon: Estudios Cor, 1960, p. 230; "O Natai do Dr. Crosby," and "Pouca Sorte com Basbeiros," both in Léah e Ourras Historles, 4th ed, (Lisbon: Estálios Cor, 1968), pp. 81 and 106, 109, 110, respectively; and "O Cosmo de Riba-Dourv," in Gente do Tenceirs Clase (Lisbon: Estúdios Cor, 1962), p. 89.

176 In the following two short stories by Migueis this theme is of major importance: "A Exquina-do-Vento," in Gerte da Terceina Carsse (Lisbon: Estádios Cor, 1962), pp. 103-104, 106-107, 109; and "Noito de Fests," Dustrio de Lisboe, Suplemento do Natel, December 24, 1963, p. 2. In tht following works this theme is of only minot importance: "Os Desentendidos," Difrio de Listoe, Vive Latendris e Arrisica, August 25, 1960, p. 17; "Fob a Chuva Purificadora," Linha Geral (Leiria, Portuggl), March 17, 1932, p. 2; "O Viajante Clindestino," "Perd50, Frau Schwarz!," both in Gexle da Terceire Clase (Lisbon: Estúdios Cot, 1962) pp. 36 and 181, respectirely; Wwa Awewhara Inquierante, 2nd st. (Lisbon: Estudios Cor 1963), pp. 136 \& 143; and "Saudades para a Dora Gencians," in Léah e Outras Mistórinz, 4th ed, (Lisban: Estudios Cor, 1968), p. 218.

${ }^{177}$ In all the following works by Miguéis this theme is of minot importance: Ritreod Feila, 3rd al.

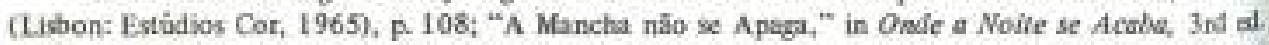
(Lisbon: Estúdjos Cor, 1960), p. 90; "O Natal do Di. Crosby, " "Saudades para a Dona Genciana," enk "O Morgado de Pedra Má," all three in Lén e Ournas Fistóvirs, 4th ed. (Lisbon: Eutádios Cor, 1968) pp. 81; 219-225; and 261. respectively; "Os Desentendidos," Ditrio de Ltsbou, Vida Litundrir e Artística, August 25, 1960, pp. 17-18. "Como Êles se Amavam! ... (Conto Verídico de Amor o d: Guerra)," (PS. IV), Ditrio de Notfleins (New Bedford, Mass.), November 26, 1940, p. 2 Signo ["L.eonardo Mareirat]; and "Porque te Calas, Améndio? " Sewa Nowe, No. 1381-1382, Navember December 1960 , pp. $340-341$.

178 In the following short stories by Migués the theme of gail is of major importance: "Perdío. Frau Sctwark!," in Gente do Tenceire Clase (Libbon: Estútios Cor, 1962), p. 188; and "Lodo," O Tempo e o Moda, No, 47. Fehraary 1967, pp. 227.228. In the following story this theme is of only minor importance: "A Esqaina-do-Vento," in Gente de Tenceiva Clarse (Lisbon: Estúdios Cor, 1962). pp. 101, 103-104, 106, 111-112. The theme of remorse is of major importance in the following shart story: "Perdsio, Frau Schurat!" in Gente da Terceine Classe (Lisbon: Estudios Cor, 1962), p. 188. It in of only minor importance in the followize short stories: "Láh," and "A Importâscia da Risca do Cabelo," both in Lásh e Oxtral Histarias, 4th ed. (Lisbon: Estidios Cor, 1968, pp. 26, 33-34; and 170 $\& 180$, respectively. 
139. This thene is of major Importance in Miguess' "O 'Crime Perfeito"," in Genfe da Terceira Clarse (Luben: Estídios Cor, 1962), p. 142, and of minor inpertance in: "A Linha Imvisivel," in Onde a Maide se Acabe, 3rd ed, (Lisbont: Estudios Cor, 1960), p. 122.

130 In the following works by Meućis this theme is of majot importance: Pdscos Feñz. 3rd ed. (Lishon: Estádios Cor, 1965), "A Mancha nïe ie A paga," and "Beleza Orgulhosa," in Onde a Norie se tabs, 3cd d, (Libbon: Estútios Cor, 1960), pp. 71 \& 89 and 267.269, respoetively; and "Como E.les x. Amavaml. .. (Conto Verídico de Amor e de Guerra),"' Difino de Noticint (New Bledford, Mass). Pt. 11. Novernber 25, 1940, p. 2; F. IV, November 26, 1940, p. 2 and PL. V, Novernber 27, 1940. p. 2. In the following two works this theme in of minor importance: "O Acidente," in Onde a Noire se Acobs, 3rdi ed. (Lisbon: Estudios Cor, 1960), Dp. 259-260: and A Escole do Paníso, 2nd ed. (Lishon: Estudios Cor, 1961), pp. 296-297, 300-301, 343.

181 In the following works by Migućis this theme is of major importance: "A Mancha nTo so Apres." "O Chapelinho Amarelo," and "Belera Orgulhosa," all three in Onde a Noile se Acabs, 3rd d. (Lisoon: Estúdios Cor, 1960), W. 97-98; 117 and 265-269, respectively. In the following works the theme is of onily minor importance: $A$ Escolt do Parsiso, 2nd od. (Liabon: Estudios Cor, 1961). if 202 \& 204; "Arroz do Céu," and "Natal Branco," both in Gente da Tercetra Classe (Lisbon: Estídios Cor, 1962), pp, 66 and 57-58, respectively.

187 Migueis published the following two articles on this subject: "Paisagens e Homens," Didrio de Libas, Vila Literírie e Artísties, October 3, 1963, pp. 17 8 19; and "O Conto Alegre de Nutal que Nio Escrevi," Dírio de Lisbos, Magrzine, December 24, 1966. D. 3. This theme is of major inportance in the following work: "O Aacl de Contrabando," in Gente do Tercein Clesse (Lisoon: Estídies Cor, 1962), pp. 113-127, It is of oely minor importanoe in the following: "A Linha Imisivel," in Onde a Noite se Acaber, 3rd ed. (Lisbon: Estúdios Cor, 1960), pp. 125-126; and Uma Avenhare Inquietante, 2nd ed, (Lisbon: Estíbtios Cor, 1963), pp. 152 \& 237.

153 In the following short story by Mieveis this theme is of major importance; "Cinzas de Incindio," in Onde a Noire se Acabe, 3td ed. (Lisbon: Estúdios Coe, 1960), Pp. 173-233; and it is of ozily minor importance in A Escola do Furatso, 2nd ed. (Lisbon: Estidios Cor, 1961). p. 327.

154

Meguêis published the following on this subject: "Exposigobs: Ar Livre (Salio Bobane)," Serar Nore. No. 29, Janury 20, 1924, pg, 104-105; "Exposiço Sousa Lopes," Seara Nona, No. 30. Jamary 31, 1924, pp. 117-118; "1. Salio d'Outono," Seara Nopa, No. 43, March 15, 1925, pA. 136-138 [Sizned "R.M."] -A Exposição de Josk Trgarro," Seara Nora, No. 117, April 12, 1928. p. 419, "Pintura de Skapinakis," Dafrio de Lisboe, Vide Literírio e Arrisrica, November 21, 1963, D.17 and pảgina central; "Cinema: Depoimesto," Seara Nows, No. 1417, November 1963, DA 201-202; ant "Eros e Mr. Chuplin - Meditaçio Sóbre a Génese do Cómico," Coldquia. No. 26, Dectmiber 1963, pp. 42-48.

165 Mieuéis' A Ercolz do Furafro, 2nd ed. (Lisbon: Estúdios Cor, 1965), pp. 72-73, 75, 76-81, 9798 \& 262: "A Düsseidorf, num Pulo," and "Perdito, Fras Schwarzl," both in Gente de Terceira Chrse (Lisbon: Estâdios Cor, 1962), pp. 172 and 182.

$18 \mathrm{e}$

In the followiny works by Mieulis this theme is of majur importance: "Ekaigma!," in Onde a Naite se Acaba, 3rd ed. (Lisbon: Estúdios Cor, 1960), pp, 7.33; and "Primeiru Encontro com 0 Trinscendente," in Gente ds Tenceinr Classe (Lisbon: Estudion Cor, 1962), pp. 189-201. In the following three works it is of only minor importance; "A Manchu nầ se A paes?" is Onde a Noile se teakg, 3nd ed. (Lisbont Estúdios Cor, 19607, Dp, 86-87 \& 91-93; "O Morgado do Pedra-ML," in Lëah e

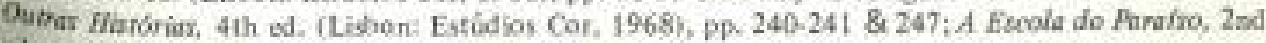
at, (1.ssoon: Estudios Cor, 1961). pp. 112, 184-186. 
187 In the following short sturies by Migaćis this theme is of major importance: "Enitmal," Onde a Noife se Acabu, 3rd ed. (Lisbon: Estútios Cor, 1960), pp. 21-23, 25, 29.31; and "Regresen Cúpula đa Pens," in Lethe e Ouinas Fistórias, 4th ed. (Lisbon: Esúdios Cor, 1968), pp. 125-128. In the following works this theme is of only minor importance: "Morte de Homem," and "A Manche nio o Apaga," both in Onde a Noite se Acsha, 3rd ed. (Lisbon: Estudios Cor, 1960), pp. 58-59 and 90-93 respectively; "O Natal do Dr. Crosby," and "O Morgado de Pedre-Má," both in Léah e Ouphaj Fistdriss, 4th ed. (Lishen: Estútios Cor, 1968), pp. 78 and 240-241, 242, respectively.

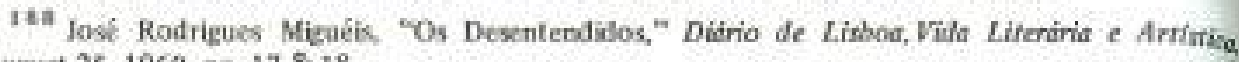
August $25,1960, \mathrm{pp}, 17 \& 18$.

159 Jose Rodrieues Migais, "Dezasseis Horas em Missio Secreta," in Léah e Outras Hitróries, 44t cd. (Lisbon: Estúdios Cor, 1968), pp 148-159.

190 José Rodrigues Miguêis, "Cinxas de Inckendio," in Onde a Naite se Acaba, 3rd ed. (Lisbeg Estísdios Cor, 1960), pp. 195-233 and "Liah," in Léwh e Oubros Histórias, 4th ed. (Lishon: Estúdios Cor, 1968), Pp. 7-35.

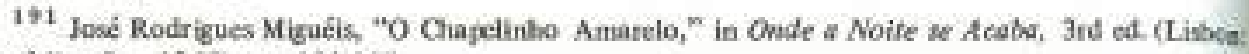
Estídios Cos, 1960), pp. 101-117.

192 José Rodrigues Migućtis, "Enigma!," in Onde a Noine sz Acabo, 3nd ed. (Lisbon: Estúdios Con, 1960), pp, 7-33.

193 Josê Rodrignos Miguéis, "Dezasscis Horns em Missảo Secreta," in Límh e Outrọ Histónien, 4th ed. (Lisbon: Estúdios Cor, 1968), pp 135-159.

194 José Rodrigues Mizuéis, "A Esquina-do-Vento," in Gente de Terceinu Casse (Lisboni Estidin Cor, 1962), pp 93-111.

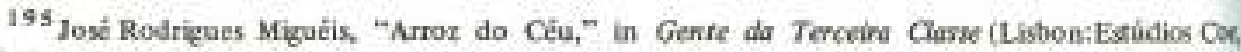
1962), pp. 63-69.

196 Josk Rodrigues Migucis, 40 Anel de Contrabando," and "O-Crime Perfeito"," both in Gente da Terceira Classe (Lisbon: Estúdios Cot, 1962), pp-113-127 and 129-149, respectivaly.

197 José Rodrigues Miqutis, "Cinas de Incëndio," and "Bckeza Orgultosa," both in Onde a Norfe te Acobs, 3nd ed. (Liston: Estúdios Cor, 1960), pp, $173-233$ and 261-271, reipectively; "O Natal de De. Crosby," "Regresso à Cupala da Pena," "Dezasseis Horas ems Misslo Secreta," "A Importincia da Risca do Cabelo," "Uma Cirreira Cortada," and "Sasdades para a Dena Genciana," all six in Léête Outras Historiss, 4th od. (Lisbon: Estúdios Cos, 1968), pp. 65-89; 115-133; 135-159; 161-199 181-195; and 197-227, respectively; "Gente da Tereeira Classe," "Arroz do Cés," "O Cosme de Riba-Douro," "A Esquina-do-Vento," "O 'Crime Perfeito'," "Perdio, Fras Schuarzl." "Primeit Encontro com o Transcendente," "Silvestrc, os Seus Amores," and " "Ite, Missa Est'," all rine in Gente de Tenceina Classe (Lisbon: Estudios Cor, 1962), pp. 7-31; 63-69; 71-91; 93-111, 129-149. 177-187: 189-201; 203-221 and 243-253, respectively; "Noite de Festa," Dibio de Lisbor, Suple merro do Naial, December 24, 1963, pp. 1 \& 2; "A Sombra," Severe Nowi, No, 112, December 22 1927, pp 313-314: "Sob a Chima Purificadora," Limhe Genal (Leiria, Portugal), March 17, 1932, p.2

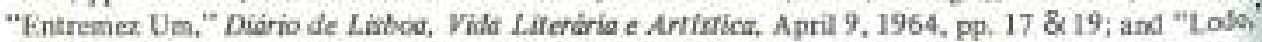
O Tempo e o Moda. No. 47, February 1967, pp. 223-229.

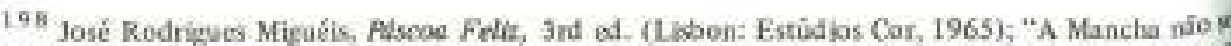
Apoga," "O Chapelinho Amarelo," "A Linba Invisíve," "Cinzas de Incündio," and "O Acidente," $3 t$ five in Onde a Noite se Acmbt, 3ri ed. (Lisbon: Estudtios Cot, 1965), pp. 69.99; 101-117; 119-1 2 ? 173-233 and 235-259, respectively; "Léah," "Uma Viagem na Nossa Terta," so Natal do De. Crodby:

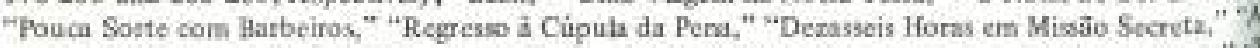
Importáneia da Rivea do Cabelo," -Uma Carrcin Cortada," and "Saudades para a Dona Genciaria," in: Letah e Ournar Bistorisr, 4th ed. (Lisbon: Estudios Cor, 1968), pp. 7-35; 37-63; 65-89; 91-11?. 
115133; 135-159; 161-179; 181-195; and 197-227, tespectively; $A$ Escols do Parciso, 2 nd ed. Liban: Estudios Cor, 1961); "Gente da Terceira Classe," "O Anel de Contrabando," "O 'Crime Purfetto", "Perdto, Fraw SchiwarzL," "Primeiro Encontro sam o Traescendeste," and "Silvestre, 09 Seas Amores," all six in Gente de Terceind Classe (Lisbon: Estidios Cor, 1962), pp. 7-31; 113-127: 127-149; 177-187; 189-201; an! 203-221; "Como Eles se Amavanl ... (Conio Yerífion đe Amor e de Guerra)," Didina de Noricas (Now Bedford, Msss.), Pt. 1, November 22, 1940, p. 2; . . II. November 11. 1940, p. 2; PL. III. November 25, 1940, p. 2; Pt. IV. November 26, 1940, P. 2; and Pt. V. November 27, 1940, p. 2; "Porque te Calas, Amíbilio? "" Seura Nova, No. 1381-1382, NovemberDecenber 1960, pp. 338-34I; "Os Desentenutidos," Diärio de Lisbos, Vide Literíni e Artistics, Aigust 25, 1960, pp. 17 \& 18; and finally, "Entremez Um," Dsírio de lisboe, Vida Literibia ef Anterice, Apeil 9, 1964, pp. 17 \& 19

109 Josk Rodrigues Migués, "Natal Branco," + Mucta Platal;," and "A Dilsseldorf, mum Pulo," pll three in Gente de Terceira Classe (Lisbos: Ertudio Cor, 1962), pP. 49-61; 151-157; and 159-175.

200 José Rodrigues Miruéis, Paiscoe Feliz, Ind ed. (Lisbon: Estádios Cor, 1965), p. 36.

201 Artur Portela Filla, [Iaterview with Jose Rodrigues Miguéis] "Fala José Rodrigues Miguẻis: Um Escritor Volta à Vida que Ele Conheceu e Viveu com Todas as Ansiedades do Tempo," Dilrio de lishoe, March 13, 1958, pp. 1 \& 14, 